\title{
Review Article \\ Recent Overview of Solar Photocatalysis and Solar Photo-Fenton Processes for Wastewater Treatment
}

\author{
A. G. Gutierrez-Mata, ${ }^{1}$ S. Velazquez-Martínez, ${ }^{1}$ Alberto Álvarez-Gallegos, ${ }^{2}$ M. Ahmadi, ${ }^{3,4}$ \\ José Alfredo Hernández-Pérez, ${ }^{2}$ F. Ghanbari, ${ }^{3,4}$ and S. Silva-Martínez ${ }^{2}$ \\ ${ }^{1}$ Posgrado en Ingeniería y Ciencias Aplicadas, Universidad Autónoma del Estado de Morelos, Av. Universidad 1001, Col. Chamilpa, \\ 62209 Cuernavaca, MOR, Mexico \\ ${ }^{2}$ Centro de Investigación en Ingeniería y Ciencias Aplicadas, Universidad Autónoma del Estado de Morelos, Av. Universidad 1001, \\ Col. Chamilpa, 62209 Cuernavaca, MOR, Mexico \\ ${ }^{3}$ Environmental Technologies Research Center, Ahvaz Jundishapur University of Medical Sciences, Ahvaz, Iran \\ ${ }^{4}$ Department of Environmental Health Engineering, Ahvaz Jundishapur University of Medical Sciences, Ahvaz, Iran
}

Correspondence should be addressed to S. Silva-Martínez; ssilva@uaem.mx

Received 22 February 2017; Revised 5 May 2017; Accepted 14 May 2017; Published 9 July 2017

Academic Editor: Manuel Ignacio Maldonado

Copyright (c) 2017 A. G. Gutierrez-Mata et al. This is an open access article distributed under the Creative Commons Attribution License, which permits unrestricted use, distribution, and reproduction in any medium, provided the original work is properly cited.

\begin{abstract}
This literature research, although not exhaustive, gives perspective to solar-driven photocatalysis, such as solar photo-Fenton and $\mathrm{TiO}_{2}$ solar photocatalysis, reported in the literature for the degradation of aqueous organic pollutants. Parameters that influence the degradation and mineralization of organics like catalyst preparation, type and load of catalyst, catalyst phase, $\mathrm{pH}$, applied potential, and type of organic pollutant are addressed. Such parameters may also affect the photoactivity of the catalysts used in the studied solar processes. Solar irradiation is a renewable, abundant, and pollution-free energy source for low-cost commercial applications. Therefore, these solar processes represent an environmentally friendly alternative mainly because the use of electricity can be decreased/avoided.
\end{abstract}

\section{Introduction}

The use of solar irradiation to detoxify contaminated effluents has recently increased and become of utmost importance for saving energy and to improve the performance of several degradation aqueous processes. Solar photocatalysis and solar photo-Fenton technologies are classified into advanced oxidation processes (AOP). The AOP involve the in situ generation of highly oxidizing radical species such as $\mathrm{OH}^{\bullet}$ by using different energy sources like chemical, natural (solar), and artificial light energy. The hydroxyl radicals, $\mathrm{OH}^{\bullet}$, are capable of transforming toxic and persistent organic compounds into harmless end products $\left(\mathrm{CO}_{2}\right.$ and mineral acids) [1]. The interaction of solar irradiation with catalysts such as iron ions $\left(\mathrm{Fe}^{3+}\right)$, in photo-Fenton, and $\mathrm{TiO}_{2}$, in photocatalysis, increases the rate of pollutant degradation by the photochemical reactions produced within these processes.

These two AOP have proved to be very effective for degrading a vast aqueous organic contaminants such as emerging [2, 3], persistent [4-9], textiles [10-13], and bacteria [14-16] pollutants.

This literature research, although not exhaustive, gives perspective to solar photo-Fenton, solar photoelectro-Fenton, and $\mathrm{TiO}_{2}$ solar photocatalytic processes reported in the literature for the degradation of aqueous organic pollutants. Solar irradiation is a renewable, abundant, and pollution-free energy source for low-cost commercial applications. Parameters that influence the degradation and mineralization of organics that may also affect the photoactivity of the catalysts used in the studied solar processes are addressed. 


\section{Fenton Processes}

Fenton oxidation process consists of the reaction between $\mathrm{H}_{2} \mathrm{O}_{2}$ and $\mathrm{Fe}^{2+}$ (1) in acidic solution to produce hydroxyl radicals $\left(\mathrm{OH}^{\bullet}\right)$, highly oxidant species responsible for pollutant degradation [17-19]:

$$
\begin{gathered}
\mathrm{H}_{2} \mathrm{O}_{2}+\mathrm{Fe}^{2+} \rightarrow \mathrm{Fe}^{3+}+\mathrm{OH}^{\bullet}+\mathrm{OH}^{-} \\
k=63 \mathrm{M}^{-1} \mathrm{~s}^{-1} .
\end{gathered}
$$

Following a chain reaction [20-26]:

$$
\begin{gathered}
\mathrm{Fe}^{3+}+\mathrm{H}_{2} \mathrm{O}_{2} \rightarrow \mathrm{Fe}^{2+}+\mathrm{HO}_{2}^{\bullet}+\mathrm{H}^{+} \\
k=1 \times 10^{-2} \mathrm{M}^{-1} \mathrm{~s}^{-1} \\
\mathrm{OH}^{\bullet}+\mathrm{H}_{2} \mathrm{O}_{2} \rightarrow \mathrm{HO}_{2}^{\bullet}+\mathrm{H}_{2} \mathrm{O} \\
k=2.7 \times 10^{7} \mathrm{M}^{-1} \mathrm{~s}^{-1}, \\
\mathrm{OH}^{\bullet}+\mathrm{Fe}^{2+} \rightarrow \mathrm{Fe}^{3+}+\mathrm{OH}^{-} \\
k=3.2 \times 10^{8} \mathrm{M}^{-1} \mathrm{~s}^{-1} \\
\mathrm{Fe}^{3+}+\mathrm{HO}_{2}^{\bullet} \rightarrow \mathrm{Fe}^{2+}+\mathrm{O}_{2}+\mathrm{H}^{+} \\
k=3.1 \times 10^{5} \mathrm{M}^{-1} \mathrm{~s}^{-1} \\
\mathrm{Fe}^{2+}+\mathrm{HO}_{2}^{\bullet}+\mathrm{H}^{+} \rightarrow \mathrm{Fe}^{3+}+\mathrm{H}_{2} \mathrm{O}_{2} \\
k=1.2 \times 10^{6} \mathrm{M}^{-1} \mathrm{~s}^{-1}, \\
\mathrm{HO}_{2}^{\bullet}+\mathrm{HO}_{2}^{\bullet} \rightarrow \mathrm{H}_{2} \mathrm{O}_{2}+\mathrm{O}_{2} \\
k=8.3 \times 10^{5} \mathrm{M}^{-1} \mathrm{~s}^{-1} \\
\mathrm{HO}_{2}^{\bullet}+\mathrm{H}_{2} \mathrm{O}_{2} \rightarrow \mathrm{OH}^{\bullet}+\mathrm{H}_{2} \mathrm{O}+\mathrm{O}_{2} \\
k=3 \mathrm{M}^{-1} \mathrm{~s}^{-1}
\end{gathered}
$$

However, according to Pignatello and collaborators [19], reaction (8) is very slow compared to those involving $\mathrm{HO}_{2}^{\circ}$ species and can be neglected.

The reaction between $\mathrm{H}_{2} \mathrm{O}_{2}$ and $\mathrm{Fe}^{3+}$ (2), referred to as Fenton-like reaction, produces less oxidant radical species $\left(\mathrm{HO}_{2}^{\circ}\right)$; nevertheless, both ferric and ferrous ion species are present simultaneously in the chain reaction (reactions (1)-(7) regardless of which is used to initiate the reaction. Thus, the $\mathrm{H}_{2} \mathrm{O}_{2}$ can be catalytically decomposed by $\mathrm{Fe}^{3+} / \mathrm{Fe}^{2+}$ into oxidant radical species [19]. The homogeneous catalytic decomposition of $\mathrm{H}_{2} \mathrm{O}_{2}$ by ferric ions may be also represented by [27-29]

$$
\begin{gathered}
\mathrm{Fe}^{3+}+\mathrm{H}_{2} \mathrm{O}_{2} \leftrightarrow \mathrm{Fe}\left(\mathrm{HO}_{2}\right)^{2+}+\mathrm{H}^{+} \\
k=3.1 \times 10^{-3}, \\
\mathrm{Fe}\left(\mathrm{HO}_{2}\right)^{2+} \leftrightarrow \mathrm{Fe}^{2+}+\mathrm{HO}_{2}^{\bullet} \\
k=2.7 \times 10^{-3} \mathrm{~s}^{-1} .
\end{gathered}
$$

The photo-Fenton process increases the amount of $\mathrm{OH}^{\bullet}$ radicals with $\mathrm{Fe}^{2+}$ regeneration (11) by the photoreduction of $\mathrm{Fe}(\mathrm{OH})^{2+}$, produced in (reaction (10)) which maxima concentration is at $\mathrm{pH} \sim 3.1[28,30]$ :

$$
\begin{array}{r}
\mathrm{Fe}^{3+}+\mathrm{H}_{2} \mathrm{O} \rightarrow \mathrm{Fe}(\mathrm{OH})^{2+}+\mathrm{H}^{+} \\
K=2.89 \times 10^{-3} \mathrm{M}^{-1}, \\
\mathrm{Fe}(\mathrm{OH})^{2+}+\mathrm{hv}(\lambda<400 \mathrm{~nm}) \rightarrow \mathrm{Fe}^{2+}+\mathrm{OH}^{\bullet}
\end{array}
$$

Thus, solar light irradiation (UV/visible irradiation) promotes photochemical reactions with light active intermediate species, such as $\mathrm{Fe}(\mathrm{OH})^{2+}$; reaction (11) produces hydroxyl radicals and regenerates $\mathrm{Fe}^{2+}$ which close the catalytic cycle of $\mathrm{OH}^{\bullet}$ generation via reaction (1). This light enhancement has been explained mainly by photolysis of hydroxide complexes of $\mathrm{Fe}^{3+}$ (reaction (11)) and photochemical reactions of ligand complexes formed between $\mathrm{Fe}^{3+} / \mathrm{Fe}^{2+}$ and organic acids (ferric carboxylic complexes) such as oxalic citric acids $[31,32]$. Nevertheless, the rate of photolysis of ferric carboxylic complexes can be several orders higher than that of hydrated ferric ions, $\mathrm{Fe}(\mathrm{OH})^{2+}$ (reaction (11)) [33, 34]. Enhancement of the photo-Fenton reaction with the use of these ligand complexes was attributed to their higher solubility and higher stability constant than that of ironorganic pollutant complexes and high photoactivity under $\mathrm{UV}$-visible light by increasing the quantum yield for $\mathrm{Fe}^{2+}$ production [35].

Table 1 summarizes the experimental degradation of several organic contaminants by solar photo-Fenton. It is shown that the oxidation degree, or mineralization, depends on several parameters like the type of reactor used, $\mathrm{pH}$, initial concentration of the organic contaminant, degradation time, among some others. The oxidation of the organic matter with time was followed by parameters like DOC, TOC, COD, and organic concentration decrease.

The main disadvantages of the Fenton process are (i) the $\mathrm{pH}$ of the solution (its optimum conditions is obtained at $\mathrm{pH}$ 2.8), (ii) sludge formation which depends on the amount and type of iron used, and (iii) $\mathrm{H}_{2} \mathrm{O}_{2}$ storage and handling and its associated cost.

2.1. The Electrochemical Fenton-Based (EF) Processes. The electrochemical Fenton-based (EF) processes, included in the electrochemical advanced oxidation processes, were developed to overcome the drawbacks of the classical Fenton (CF) process. These processes in situ generate the Fenton reagents $\left(\mathrm{H}_{2} \mathrm{O}_{2}\right.$ and/or $\left.\mathrm{Fe}^{2+}\right)$ to yield $\mathrm{OH}^{\bullet}$ radicals $[36,37]$. The EF processes such as Fered-Fenton (EF-FeRe) [38, 39], electrochemical peroxidation/anodic Fenton (EF-FeOx) [40-42], electro-Fenton $\left(\mathrm{EF}-\mathrm{H}_{2} \mathrm{O}_{2}-\mathrm{FeRe}\right)$ [38, 43], and peroxi-coagulation $\left(\mathrm{EF}-\mathrm{H}_{2} \mathrm{O}_{2}-\mathrm{FeOx}\right)[44,45]$ increase the efficiency of pollutant degradation. The efficiency of pollutant degradation is enhanced when UV light or solar irradiation is used in combination with CF (photo-Fenton or solar photo-Fenton) and EF (photoelectro-Fenton or solar photoelectro-Fenton) processes. Figure 1 schematically shows CF and EF processes: (1) CF: addition of both reagents to the solution, (2) EF-FeRe: addition of both reagents to the solution with the regeneration of $\mathrm{Fe}^{2+}$ from reaction (13), (3) EF-FeOx: generation of iron anions using a sacrificial iron anode with the addition of hydrogen peroxide, (4) EF$\mathrm{H}_{2} \mathrm{O}_{2}$-FeRe (the most common electrochemical Fenton- 


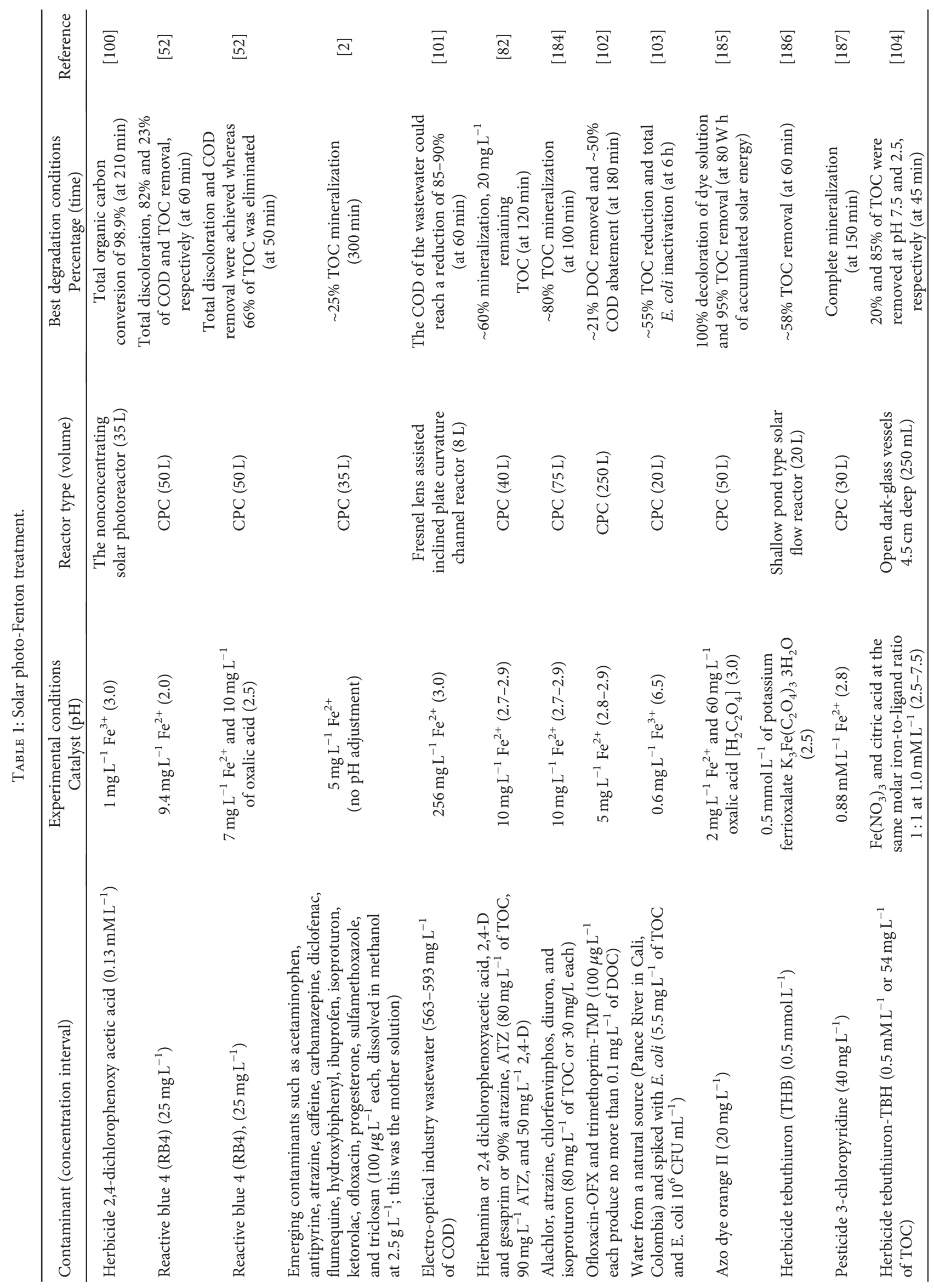




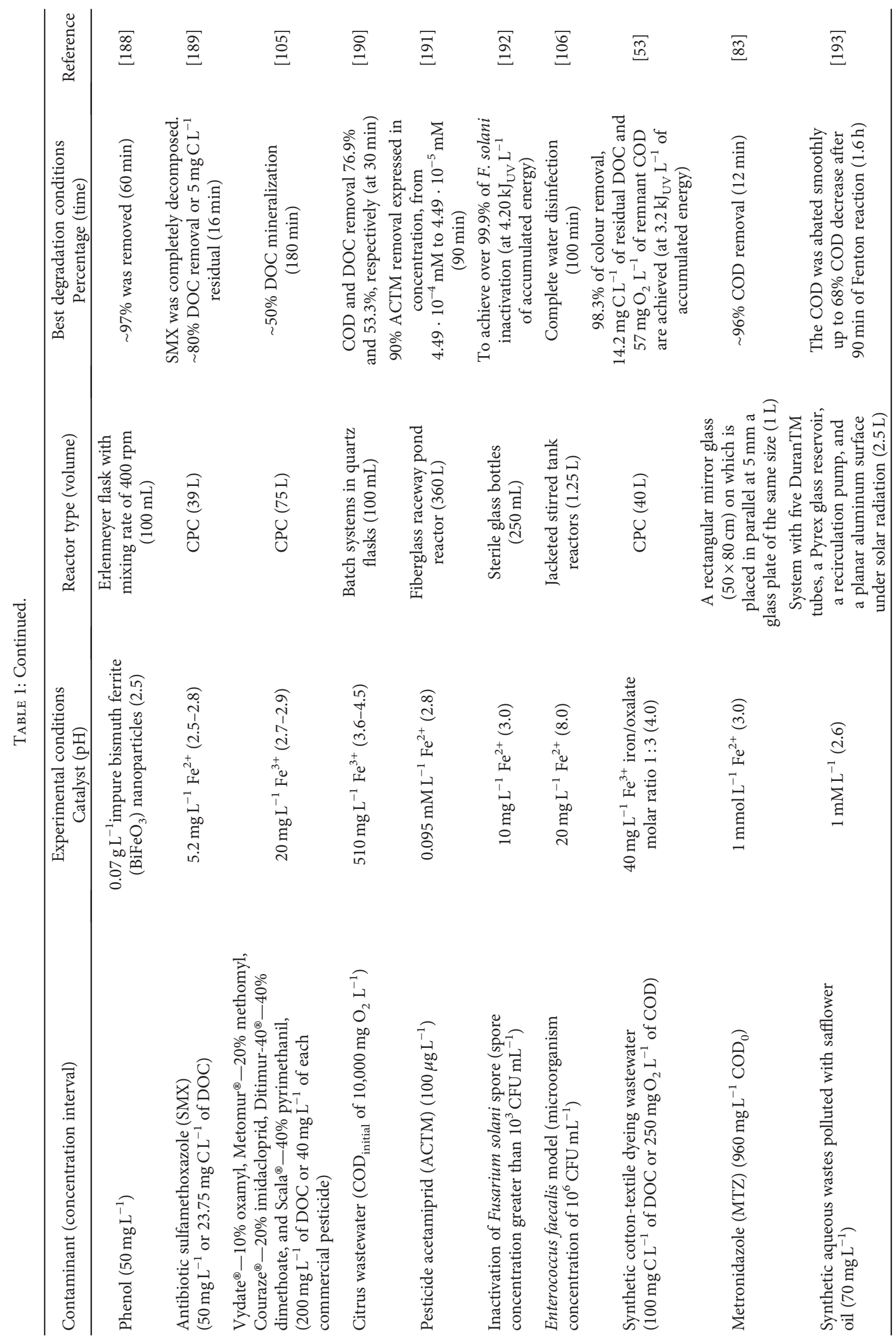




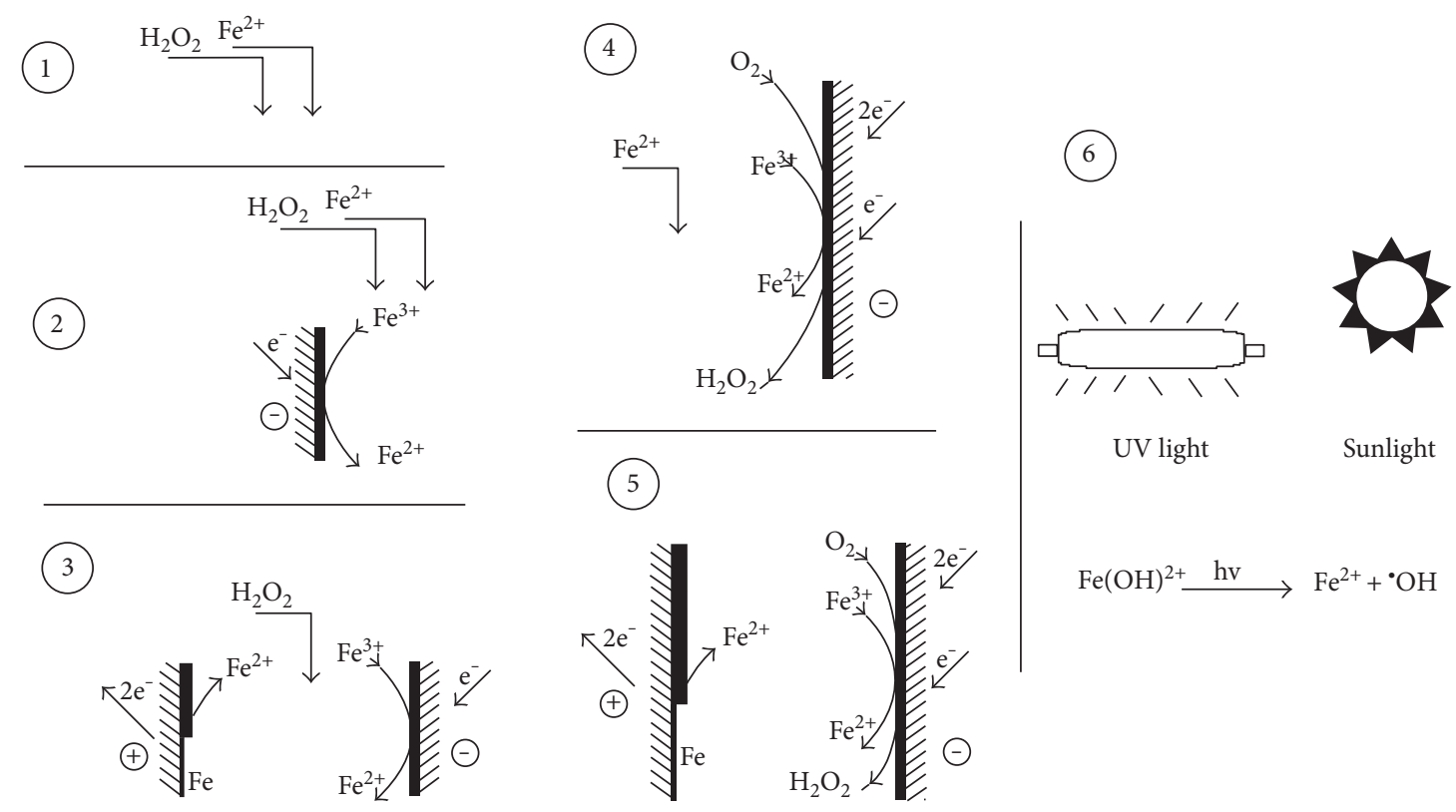

Figure 1: Classical Fenton (CF) and electrochemical Fenton (EF) oxidation processes: (1) CF, (2) Fered-Fenton (EF-FeRe), (3) electrochemical peroxidation/anodic Fenton (EF-FeOx), (4) electro-Fenton $\left(\mathrm{EF}-\mathrm{H}_{2} \mathrm{O}_{2}-\mathrm{FeRe}\right)$, (5) peroxi-coagulation $\left(\mathrm{EF}-\mathrm{H}_{2} \mathrm{O}_{2}-\mathrm{FeOx}\right)$, and (6) UV-CF/UV-EF.

based process, known as electro-Fenton): generation of hydrogen peroxide and regeneration of initially added $\mathrm{Fe}^{2+}$ catalyst, (5) $\mathrm{EF}-\mathrm{H}_{2} \mathrm{O}_{2}-\mathrm{FeOx}$ : in situ generation of both hydrogen peroxide and iron anions, and finally, (6) CF and EF combined with UV light or solar irradiation.

The hydrogen peroxide is generated in situ from the twoelectron oxygen reduction on cathodes such as reticulated vitreous carbon [46], gas diffusion electrodes [47], carbon felt $[48,49]$, pristine graphene [50], and boron-doped diamond [51] from reaction (12), and $\mathrm{Fe}^{2+}$ can be electrochemically regenerated, if it was initially added to the solution (reaction (13)) or electrochemically generated from a sacrificial iron anode (reaction (14)).

$$
\begin{array}{r}
\mathrm{O}_{2}+2 \mathrm{H}^{+}+2 \mathrm{e}^{-} \rightarrow \mathrm{H}_{2} \mathrm{O}_{2} \\
\mathrm{Fe}^{3+}+\mathrm{e}^{-} \rightarrow \mathrm{Fe}^{2+} \\
\mathrm{Fe}-2 \mathrm{e}^{-} \rightarrow \mathrm{Fe}^{2+}
\end{array}
$$

2.2. Solar Photoelectro-Fenton. The conventional photoFenton reaction showed a limited efficiency in the mineralization of real textile wastewater mainly associated to three factors [10, 35, 52-55]: (i) formation of iron-organic pollutant complexes with low solubility at acidic $\mathrm{pH}$ values (2.8), leading to iron precipitation and abatement of dissolved organic carbon, cannot be associated with mineralization; (ii) low photoactivity of the iron-organic pollutant complexes under UV-visible light; and (iii) photoreduction via a ligandto-metal charge mechanism, which occurs on the surface of the iron precipitates, is very slow.

The photo-Fenton reaction can be enhanced by the following:
(1) The use of different iron(III)-organic ligand complexes such as $\mathrm{Fe}(\mathrm{III})$-oxalate, $\mathrm{Fe}(\mathrm{III})$-citrate and $\mathrm{Fe}(\mathrm{III})$-EDDS (EDDS: S,S'-ethylenediamine-N, $\mathrm{N}^{\prime}$ disuccinic acid tri-sodium salt). These ligand complexes have higher solubility and higher stability constant than iron-organic pollutant complexes which prevent iron precipitation that allows to achieve proper mineralization. The superiority of $\mathrm{Fe}(\mathrm{III})$-oxalate over $\mathrm{Fe}(\mathrm{III})$-citrate and $\mathrm{Fe}(\mathrm{III})$ EDDS complexes can be mainly associated to the different quantum yield values for $\mathrm{Fe}(\mathrm{II})$ production and the half-life of the Fe(III)-organic ligand complexes under UVA radiation. The photo-Fenton reaction mediated by ferricarboxylates was characterized by an initial fast reaction rate, mainly associated to the fast regeneration of $\mathrm{Fe}^{3+}$ to $\mathrm{Fe}^{2+}$, enhanced by the photodecarboxylation of ferricarboxylate complexes under UV-visible light, followed by a very slow reaction rate with a low consumption of $\mathrm{H}_{2} \mathrm{O}_{2}$ due to the disappearance of oxalic acid and free iron species complex with other organic oxidation by-products which reduced substantially the dissolved iron concentration and consequently the reaction rate [35].

(2) The use of electricity to drive the photo-Fenton process electrochemically (photoelectro-Fenton (PEF)) under sunlight [56]. The PEF process accelerates the degradation of pollutants because of (a) the enhancement of $\mathrm{Fe}^{2+}$ regeneration and $\mathrm{OH}^{*}$ production by the photolytic reaction (11) and (b) the photolysis of Fe-complexes with generated intermediates like carboxylic acids by reaction (15) [57-59]: 


$$
\mathrm{Fe}(\mathrm{OOCR})^{2+} \stackrel{\mathrm{hv}}{\rightarrow} \mathrm{Fe}^{2+}+\mathrm{R}^{\bullet}+\mathrm{CO}_{2}
$$

An interesting comparison of the performance of solar photo-Fenton and solar photoelectro-Fenton experiments, at laboratory scale, was carried out by Serra and collaborators [60]. These authors studied the degradation of the amino acid a-methylphenylglycine (a soluble and nonbiodegradable target pollutant) and observed that the solar-driven photoFenton is the most environmentally friendly alternative, mainly because of the use of electricity in the solar photoelectro-Fenton experiments [60]. Indeed, the solar photoelectro-Fenton (SPEF) process can be driven by a photovoltaic system when scale up to a pilot plant or solar plant to decrease the costs associated with the consumption of electricity, which may make sustainable the whole process. Having this in mind, a self-sustainable SPEF, driven by a photovoltaic cell, was designed to study the oxidation of the antibiotic trimethoprim (TMP), producing a high degree of mineralization. Tenaromatic intermediates generated from hydroxylation, carbonylation, and demethylation reactions were identified together with three carboxylic acids (oxamic, oxalic, and formic acids) and two inorganic ions $\left(\mathrm{NH}_{4}^{+}\right.$ and $\mathrm{NO}_{3}^{-}$). This study is a cost-effective approach for TMP degradation and demonstrated that the sunlight can provide the electric power (for mechanical systems) and the UV radiation for SPEF process [61].

Almeida and coworkers [62] studied the degradation of paracetamol by solar photoelectro-Fenton using a flow plant with a Pt/carbon-PTFE air-diffusion electrochemical cell (one-compartment filter-press reactor) coupled with a compound parabolic collector. The $\mathrm{H}_{2} \mathrm{O}_{2}$ was electrogenerated from the cathodic $\mathrm{O}_{2}$ reduction at the carbon-PTFE airdiffusion electrode (ADE). These authors reported $75 \%$ of total organic carbon (TOC) decrease with an energy cost of $93 \mathrm{kWh} \mathrm{kg}^{-1}$ TOC $\left(7.38 \mathrm{kWh} \mathrm{m}^{-3}\right)$ and $71 \%$ removal efficiency. $80 \%$ TOC removal was the maximum value acquired at $150 \mathrm{~min}$, with conversion of $79 \%$ of initial $\mathrm{N}$ into $\mathrm{NH}_{4}^{+}$ ion. Thus, according to these authors, total mineralization of paracetamol was not attained because of the formation of $\mathrm{N}^{-}$derivatives and other undetected products that cannot be destroyed by radical $\mathrm{OH}^{\bullet}$ and UV light. The same solar flow plant used by Almeida et al. was employed to oxidize azo dyes [63] and the antibiotic metronidazole [64] by electro-Fenton (EF) and solar photolectro-Fenton (SPEF) processes. Ruiz and coworkers observed that the EF process yielded rapid decolorization with poor TOC removal, and Pérez et al. also reported very weak mineralization of the antibiotic. These results were attributed to the formation of persistent carboxylic acids like oxalic acid as the major component of final electrolyzed solutions; conversely, quick photolysis of $\mathrm{Fe}$ (III)-oxalate complexes by UV light of solar irradiation explained the higher oxidation power of SPEF that gave almost total mineralization of the organic contaminants under study. It was described that the incident UV light played an important role in the photodecomposition of several $\mathrm{N}$-derivatives that favored the release of ammonium ions and the loss of volatile $\mathrm{N}$-compounds. Espinoza and coworkers [65] reported that the elimination of an diazo dye (acid yellow 42 dye) and its organic intermediates was due to hydroxyl radicals formed both at the anode surface from water oxidation and in bulk solution from Fenton reaction between electrogeneratd $\mathrm{H}_{2} \mathrm{O}_{2}$ and added $\mathrm{Fe}^{2+}$. The application of solar radiation in the photolectro-Fenton process yielded higher current efficiencies and lower energy consumptions than electro-Fenton (EF) and electro-oxidation, with electrogenerated $\mathrm{H}_{2} \mathrm{O}_{2}$ by the additional production of hydroxyl radicals from the photolysis of $\mathrm{Fe}(\mathrm{III})$-hydrated species (reaction (11)), and the photodecomposition of $\mathrm{Fe}(\mathrm{III})$-complexes with organic intermediates (ferric carboxylic complexes, like ferric oxalate) that pass through an excitation state under the influence of photons of UV/vis wavelengths. This reaction is called the ligand-metal charge transfer reaction [66-68]:

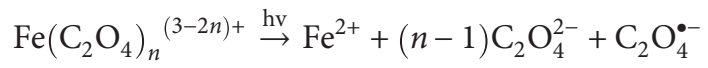

Table 2 summarizes the experimental degradation of several organic contaminants by solar photoelectro-Fenton. It is shown that the oxidation degree, or mineralization, depends on several parameters like the type of reactor used, $\mathrm{pH}$, initial concentration of the organic contaminant, degradation time, among some others. The oxidation of the organic matter with time was followed by parameters like DOC, TOC, COD, and organic concentration decrease.

\subsection{Influencing Parameters on the Degradation of Organic} Compounds by Solar Photoelectro-Fenton Process. Complete transformation of organic compounds to $\mathrm{CO}_{2}$ by the solar photoelectro-Fenton process depends directly on the applied current density, the concentration of catalyst, organic concentration, and the solar radiation intensity $[65,69,70]$. There are other parameters like $\mathrm{pH}$ of the solution, temperature, and electrode materials that are important too in the photoelectro-Fenton process; however, Fenton reaction is efficient at the $\mathrm{pH}$ interval of $2.5<\mathrm{pH}<3$ [7, 71-73], oxygen is needed to produce $\mathrm{H}_{2} \mathrm{O}_{2}$, and its solubility is affected by the temperature [74]; thus, it is better to perform the experiment at room temperature, and the electrode materials like carbonaceous cathodes $[46,48-50]$ and BDD anodes $[56,75]$ have been proved to be the best materials (to reduce oxygen and to produce $\mathrm{OH}^{\bullet}$ radicals, resp.) so far.

2.3.1. Current Density Influence. The current density (or voltage cell) applied to the electrochemical cell for $\mathrm{H}_{2} \mathrm{O}_{2}$ production in the photoelectro-Fenton process influences the electrode surface reaction kinetics and the extension of electrode reactions. Hydroxyl radicals are in situ generated in the photoelectro-Fenton process. Such oxidant species can be produced simultaneously via oxygen cathodic reduction (reaction (12)) in the presence of catalyst (reactions (1) and (8)) and on the anode boron-doped diamond (BDD) [75]:

$$
\mathrm{BDD}+\mathrm{H}_{2} \mathrm{O} \rightarrow \mathrm{BDD}\left(\mathrm{OH}^{\bullet}\right)+\mathrm{H}^{+}+\mathrm{e}^{-}
$$

$\operatorname{BDD}\left(\mathrm{OH}^{\bullet}\right)$ enhances the destruction of aromatic pollutants and their aliphatic intermediates such as short-linear carboxylic acids [56]. Thus, the oxidation power of the solar 


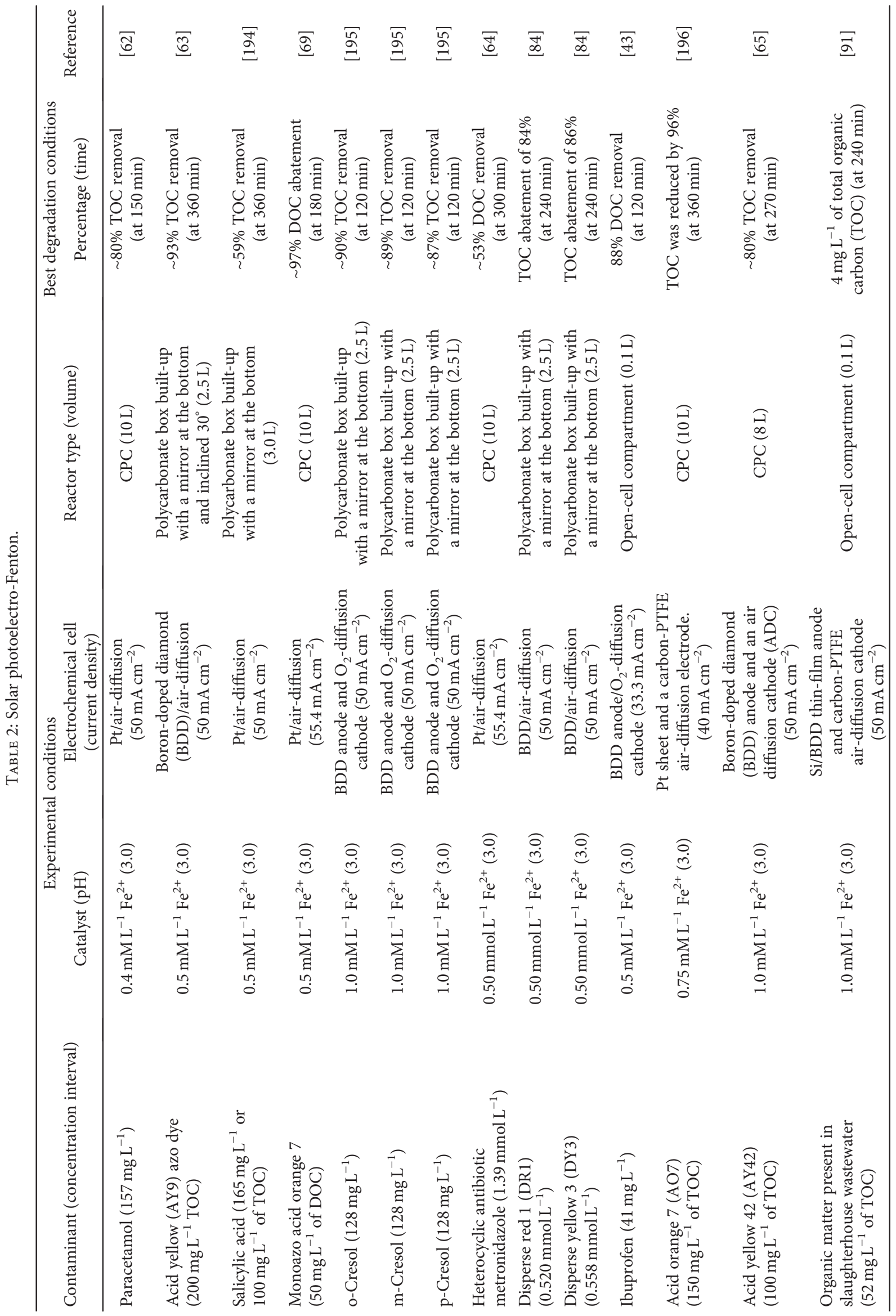




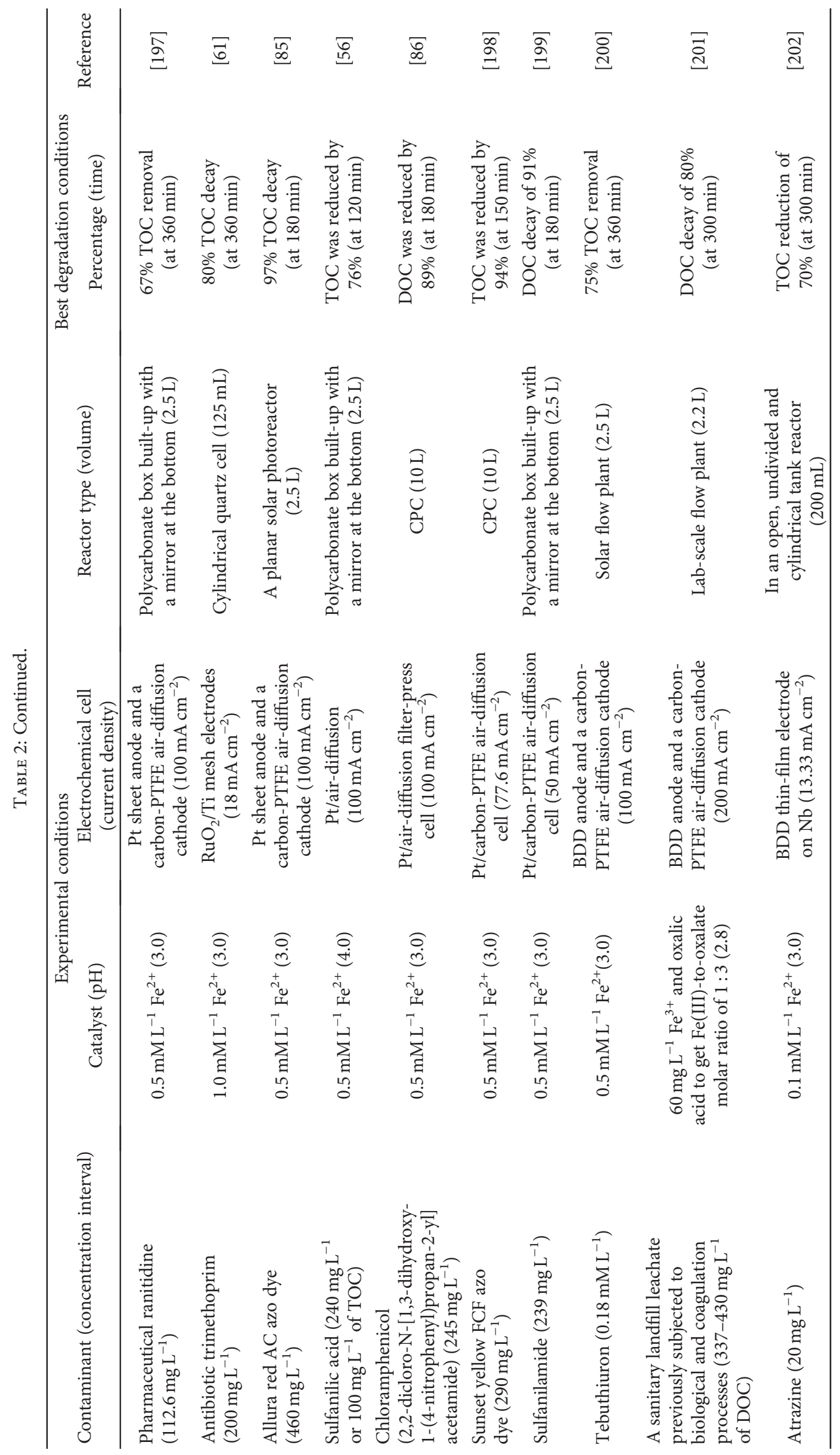


photoelectro-Fenton is additionally enhanced by reactions (11) and (15) under the solar radiation.

Garcia-Segura and collaborators [76] claimed that at current densities $>33.3 \mathrm{~mA} \mathrm{~cm}^{-2}$, the removal rate of oxalic and oxamic acids was not improved because of the occurrence of parasitic reactions, such as nonorganic oxidizing reactions with hydroxyl radicals, which led to an efficiency, decrease at higher current densities. According to these authors, the parasitic reactions limited the mass transport of acids to the electrodes and increased largely the electric charge consumption. A drop-in TOC mineralization of the antibiotic sulfamethoxazole by photoelectro-Fenton which was observed when the current density reached $25 \mathrm{~mA} \mathrm{~cm}^{-2}$ was also reported [61, 77]. This drop was attributed to (i) an increase in the degree of cathode polarization as the current density increased, resulting in $\mathrm{H}_{2} \mathrm{O}_{2}$ decomposition to $\mathrm{H}_{2} \mathrm{O}$ on the anode [59]; (ii) reduction of $\mathrm{H}_{2} \mathrm{O}$ to $\mathrm{H}_{2}$ [78]; and (iii) $\mathrm{Fe}^{2+}$ present in the solution is anodically oxidized to $\mathrm{Fe}^{3+}$, and $\mathrm{OH}^{\bullet}$ is dimerized to $\mathrm{H}_{2} \mathrm{O}_{2}$ (reaction (18)) [59]. It should be noted that the dimerization generally occurs at higher concentration of hydroxyl radicals, and such higher concentration is possible with the higher voltage (or current) applied [79].

$$
2 \mathrm{OH}^{\bullet} \rightarrow \mathrm{H}_{2} \mathrm{O}_{2}
$$

Additionally, to these parasitic reactions, there is the oxidation of $\mathrm{BDD}\left(\mathrm{OH}^{\bullet}\right)$ to $\mathrm{O}_{2}$ (reaction (19)) together with reactions (3), (4), and (18) [65].

$$
2 \mathrm{BDD}\left(\mathrm{OH}^{\bullet}\right) \rightarrow 2 \mathrm{BDD}+\mathrm{O}_{2}+2 \mathrm{H}^{+}+2 \mathrm{e}^{-}
$$

The quantity of $\mathrm{BDD}\left(\mathrm{OH}^{\bullet}\right)$ may also decrease because of the increase in the formation rate of other weaker oxidants at the BDD anode, such as the peroxodisulfate $\left(\mathrm{S}_{2} \mathrm{O}_{8}^{2-}\right)$ ion by oxidation of $\mathrm{SO}_{4}^{2-}$ from the electrolyte (reaction (20)) and ozone generation (reaction (21)) [75]:

$$
\begin{gathered}
2 \mathrm{HSO}_{4}^{-} \rightarrow \mathrm{S}_{2} \mathrm{O}_{8}^{2-}+2 \mathrm{H}^{+}+2 \mathrm{e}^{-} \\
3 \mathrm{H}_{2} \mathrm{O} \rightarrow \mathrm{O}_{3}+6 \mathrm{H}^{+}+6 \mathrm{e}^{-}
\end{gathered}
$$

Thus, using an appropriated current density can prevent such side reactions and also avoid using high energy consumption.

2.3.2. Effect of the Concentration of Ferrous Ions. The $\mathrm{Fe}^{2+}$ catalyst concentration is an important parameter that limits the rate of Fenton reaction (1) to produce hydroxyl radicals and, therefore, affects the degree of mineralization of the organic contaminants. The decrease in the oxidation power of Fenton reaction is related to the competitive reaction between $\mathrm{Fe}^{2+}$ and $\mathrm{OH}^{\bullet}$ (4) which can also be photolyzed [80], reaction (11).

There are experimental evidences that the decolorization rate of azo dyes dropped gradually with increasing the initial ferrous ion content $[65,70]$. Espinoza et al. [65] observed that concentration of $\mathrm{Fe}^{2+} \geq 2 \mathrm{mmol} \mathrm{L}^{-1}$ decreased the decolorization which was attributed to reaction (4); also, there were produced colored compounds that decreased the effect of solar radiation, and therefore, the removal of the dye was disfavored. Furthermore, there might have been the generation of unwanted reactions like the formation of $\mathrm{Fe}^{3+}$ complexes $((22)$ and (23)) that would have prevented the regeneration of $\mathrm{Fe}^{2+}$ or slowed the process $[65,70]$ :

$$
\begin{gathered}
\mathrm{Fe}^{3+}+\mathrm{OH}^{\bullet} \rightarrow \mathrm{Fe}(\mathrm{OH})^{3+} \\
2 \mathrm{Fe}^{3+}+(2 n-1) \mathrm{C}_{2} \mathrm{O}_{4}^{2-} \rightarrow 2 \mathrm{Fe}\left(\mathrm{C}_{2} \mathrm{O}_{4}\right)_{n}{ }^{(3-2 n)+}
\end{gathered}
$$

Feng and collaborators [81] reported that the degradation rate of the anti-inflammatory drug ketoprofen decreased with increasing $\mathrm{Fe}^{2+}$ concentration up to $1.0 \mathrm{mmol} \mathrm{L}^{-1}$. Fast degradation rate of ketoprofen by electro-Fenton was achieved at concentration of $0.1 \mathrm{mmol} \mathrm{L}^{-1} \mathrm{Fe}^{2+}$. Further increase in catalyst concentration resulted in the decrease of oxidation rate due to the competitive reaction between $\mathrm{Fe}^{2+}$ and $\mathrm{OH}^{\bullet}(4)$.

2.3.3. Influence of Initial Concentration of the Organic Compound. Generally, an increase in contaminant concentration produces a decrease in the extent of the organic compound mineralization. The oxidation of high amounts of contaminant molecules by the hydroxyl radical species becomes slower since a number of intermediate species are also produced that demand more $\mathrm{OH}^{\bullet}[61,82-89]$, but a constant amount of hydroxyl radicals is produced during fixed experimental conditions used. Fryda and coworkers [90] claimed that the chemical oxygen demand (COD) reduction is a highly suitable parameter for wastewater treatment, in most cases independent of the class or organic pollutants. These authors stated that a COD content between $100 \mathrm{mg} \mathrm{L}^{-1}$ to $25 \mathrm{~g} \mathrm{~L}^{-1}$ is a cost-effective and efficient range for advanced oxidation processes.

Ammar and collaborators reported that slower abatement of the target compound was observed as its content increased [83]. This was attributed to the following: (i) the amount of $\mathrm{OH}^{\bullet}$ generated continuously into the reactor was constant, and thus, it limited the disappearance of the organic pollutant, and (ii) when the organic matter in the solution is sufficiently high, a minor quantity of hydroxyl radicals attacks the pollutant molecules because more amounts of them destroy its intermediates. Similar results were reported by Samet et al., in which the removal of COD decreased as the initial COD content increased in the treated solution [89]; such results were observed using different $\mathrm{H}_{2} \mathrm{O}_{2} / \mathrm{Fe}^{2+}$ molar ratios under solar photo-Fenton process.

2.3.4. Influence of Solar Radiation. The naturally occurring wavelengths from the solar radiation, mainly those from the UV and visible radiation wavelengths, produce different photochemical reactions. The solar light is expected to improve the performance of artificial UVA lamps since it provides photons in the UV range of $300-400 \mathrm{~nm}$, as well as in the visible range of $400-650 \mathrm{~nm}$ which can also be absorbed by reactants in reactions (11) and (15), respectively $[43,65,91-94]$. There are several designs of solar reactors to 
concentrate and use efficiently the solar irradiation in the solar photo-Fenton and solar photoelectro-Fenton processes.

2.4. Combination of Solar Photo-Fenton and Solar Photoelectro-Fenton with Other Treatment Processes. The advanced oxidation processes (AOP) are environmentally friendly technologies and have shown the capability of mineralizing organic pollutants [9, 19, 35, 95-98]. Inside the AOP, the electrochemical advanced oxidation processes (EAOP) are versatile processes, like solar photoelectro-Fenton, that can produce hydroxyl radical species under controlled optimal conditions with the application of an electric current that enables high hydroxyl radical production $[43,61,64,65]$. Hence, the hydroxyl radicals, produced by the solar photoelectro-Fenton, can be used initially to oxidize recalcitrant organics and transform them into nontoxic biodegradable species; then, such intermediate compounds can be treated by the biological treatment used as posttreatment process. An anaerobic biological treatment followed by solar photoelectro-Fenton process to oxidize organic matter present in slaughterhouse wastewater from a Chilean meat company was investigated [91]. It was observed that the combination of both processes produced a totally clarified, odorless effluent, without solids in suspension and higher chemical oxygen demand removal than the one from the separate processes.

It has also been shown that the solar photo-Fenton can be used as a pretreatment for the secondary treatment process. Ballesteros and coworkers [88] proposed a strategy for treating water with high pesticide concentrations to overcome the low biodegradability of solar photo-Fenton intermediates; such strategy consisted of mixing the contaminated water with a biodegradable carbon source before biological oxidation. Hence, this combination of photo-Fenton and acclimatized activated sludge in several SBR cycles led to complete biodegradation of a concentrated pesticide solution of $500 \mathrm{mg} \mathrm{L}^{-1}$ dissolved organic carbon (DOC) in $\sim 5 \mathrm{~h}$ with a carbon removal efficiency of $90 \%$. According to GarcíaMontaño and coworkers [99], the Fenton process at pilot plant can be used as a biological pretreatment. Since after certain time and under experimental conditions, treated dye solutions became enough biocompatible to be fully biodegraded in the IBR reactor, attaining residual DOC values close to the $20 \mathrm{mg} \mathrm{L}^{-1}$ corresponding to biomass metabolites.

There are several papers devoted to oxidize many organic contaminants (like microcontaminants, herbicides, textile dyes, landfill leachates, and emergent contaminants) by solar photo-Fenton and solar photoelectro-Fenton (as depicted in Tables 1 and 2) using solar compound parabolic collectors and solar pilot reactors [2, 52, 53, 82, 88, 100-108]. Most of these studies claimed that photo-Fenton enhanced the degradation of the organic compounds achieving over $50 \%$ TOC removal. Also, bacteria inactivation by solar photo-Fenton at near-neutral $\mathrm{pH}$ using a CPC solar reactor led to a simultaneous decrease of TOC (55\%) and total E. coli inactivation with the absence of bacterial regrowth during $24 \mathrm{~h}$ in the dark [103].

The solar photo-Fenton degradation of the 2,4-dichlorophenoxyacetic acid (2,4-D) herbicide in solar pilot-plant reactors was carried out by Conte et al. [100]. These authors proposed a kinetic model to predict the reactant concentrations during the degradation and reported that the solar reactor was able to reach complete degradation of both the 2,4-D and the main intermediate (2,4-dichlorophenol) at 60 min with $98.9 \%$ of total organic carbon (TOC) conversion at $210 \mathrm{~min}$.

Durán and collaborators [52] observed that the solar photo-Fenton in the presence of oxalic acid (solar photoFenton-ferrioxalate) increased the degradation rate of reactive blue 4 since ferrioxalates strongly absorb a higher portion of the solar spectrum. The addition of oxalic acid increased the operational costs but reduced the $\mathrm{pH}$ of the solution. Thus, under optimum conditions, a $66 \%$ of TOC elimination with total discoloration and total chemical oxygen demand (COD) removal was achieved. High enhancement of the biodegradability of textile synthetic wastewater with the use of oxalic acid in the solar photoFenton process (ferrioxalate) was also reported [53]; in such study, the iron precipitated when over $70 \%$ of the initially added oxalic acid was photodecarboxylated. Clearly, the ferric-organic ligand complexes prevent iron precipitation, produce a higher amount of hydroxyl radicals (allowing to use efficiently the solar irradiation), and permit to achieve proper mineralization [35].

Table 3 summarizes the degradation of several organic contaminants at pilot scale using sand filter and microfiltration as pretreatment for the solar photo-Fenton process. Also, it reports the solar photo-Fenton process as pretreatment of the secondary treatment process. It is interesting to note that the volume treated was relatively high and that the mineralization achieved depended on the initial experimental conditions, degradation time, type of contaminants, and their initial concentration. The oxidation of the organic matter with time was followed by parameters like DOC, TOC, and organic concentration decrease.

\section{3. $\mathrm{TiO}_{2}$ Solar Photocatalysis}

$\mathrm{TiO}_{2}$ has proven to be one of the most promising photocatalysts amongst several metal oxide semiconductors because of its high reactivity, chemical stability, low cost, and nontoxicity [109]. $\mathrm{TiO}_{2}$ photocatalyst has been mainly used widely in environmental remediation (i.e., wastewater detoxification) and solar energy conversion $[96,110] . \mathrm{TiO}_{2}$ (band gap energy $3.2 \mathrm{eV})$ upon illumination with UV light $(\lambda<380 \mathrm{~nm})$ produces excited high-energy states of electron (in the conduction band, $\mathrm{e}_{\mathrm{cb}}^{-}$) and hole (in the valence band, $\mathrm{h}_{\mathrm{vb}}^{+}$) pairs, reaction (24), capable of initiating chemical reactions [111], as shown in the photocatalysis mechanism (Scheme 1).

$$
\mathrm{TiO}_{2}+\mathrm{hv} \rightarrow \mathrm{e}_{\mathrm{cb}}^{-}+\mathrm{h}_{\mathrm{vb}}^{+}
$$

The holes are responsible for the degradation of organic compounds and can react with water (reaction (25)) or hydroxyl ions (reaction (26)) to produce hydroxyl radicals; though, the recombination of the $\mathrm{e}_{\mathrm{cb}}^{-} / \mathrm{h}_{\mathrm{vb}}^{+}$pair (reaction (27)) and the reduction of $\mathrm{OH}^{\bullet}$ radicals (reaction (28)) produce large inefficiencies in the photocatalytic process [112]. 
TABLE 3: Solar photo-Fenton coupled with other treatment processes.

\begin{tabular}{|c|c|c|c|c|c|}
\hline $\begin{array}{l}\text { Contaminant } \\
\text { (concentration } \\
\text { interval) }\end{array}$ & $\begin{array}{l}\text { Experimental } \\
\text { conditions } \\
\text { Catalyst }(\mathrm{pH}) \\
\end{array}$ & $\begin{array}{l}\text { Reactor type } \\
\text { (volume) }\end{array}$ & $\begin{array}{c}\text { Best degradation conditions } \\
\text { Percentage (time) }\end{array}$ & Coupled treatment & Reference \\
\hline $\begin{array}{l}\text { Procion Red H-E7B } \\
\left(25 \mathrm{mg} \mathrm{L}^{-1}\right)\end{array}$ & $\begin{array}{l}\quad 2 \mathrm{mg} \mathrm{L}^{-1} \mathrm{Fe}^{2+} \\
(2.8-3.0 \text { for SPF } \\
\text { and neutral for BT) }\end{array}$ & CPC $(35 \mathrm{~L})$ & $\begin{array}{c}30 \% \text { DOC removal in } \\
\text { photo-Fenton pre-treatment } \\
\text { (13 min only photo-Fenton process) }\end{array}$ & $\begin{array}{l}\text { The photo-Fenton process } \\
\text { precedes an aerobic } \\
\text { biological treatment carried } \\
\text { out in an immobilised } \\
\text { biomass reactor (IBR). }\end{array}$ & [99] \\
\hline $\begin{array}{l}\text { Cibacron Red FN-R } \\
\left(250 \mathrm{mg} \mathrm{L}^{-1}\right)\end{array}$ & $\begin{array}{l}5 \mathrm{mg} \mathrm{L}^{-1} \mathrm{Fe}^{2+} \\
(2.8-3.0 \text { for SPF } \\
\text { and neutral for BT) }\end{array}$ & CPC (35 L) & $\begin{array}{c}67 \% \text { DOC removal in } \\
\text { photo-Fenton pretreatment } \\
\text { (22 min only photo-Fenton process) }\end{array}$ & $\begin{array}{l}\text { The photo-Fenton process } \\
\text { precedes an aerobic } \\
\text { biological treatment carried } \\
\text { out in an immobilised } \\
\text { biomass reactor (IBR). }\end{array}$ & [99] \\
\hline $\begin{array}{l}\text { Pesticides: Vydate, } \\
\text { Metomur, Couraze, } \\
\text { Ditumur, and Scala } \\
\left(500 \mathrm{mg} \mathrm{L}^{-1} \mathrm{DOC}\right)\end{array}$ & $\begin{array}{c}20 \mathrm{mg} \mathrm{L}{ }^{-1} \mathrm{Fe}^{2+} \\
(2.7-2.9 \text { for SPF } \\
\text { and neutral for BT) }\end{array}$ & $\mathrm{CPC}(50 \mathrm{~L})$ & $\begin{array}{l}\text { Carbon removal efficiency of } \\
\text { the combined process was as high } \\
\text { as } 90 \% \text {. activated sludge } \\
\text { acclimatization with several SBR } \\
\text { cycles led to complete } \\
\text { biodegradation in less than } 5 \mathrm{~h}\end{array}$ & $\begin{array}{l}\text { The photo-Fenton process } \\
\text { precedes a biotreatment } \\
\text { with acclimatized activated } \\
\text { sludge in several } \\
\text { sequencing batch eactor } \\
\text { (SBR) cycles }\end{array}$ & [88] \\
\hline
\end{tabular}

$$
\begin{aligned}
\mathrm{H}_{2} \mathrm{O}+\mathrm{h}_{\mathrm{vb}}^{+} & \rightarrow \mathrm{OH}^{\bullet}+\mathrm{H}^{+} \\
\mathrm{OH}^{-}+\mathrm{h}_{\mathrm{vb}}^{+} & \rightarrow \mathrm{OH}^{\bullet} \\
\mathrm{h}_{\mathrm{vb}}^{+}+\mathrm{e}_{\mathrm{cb}}^{-} & \rightarrow \mathrm{TiO}_{2}+\text { heat } \\
\mathrm{OH}^{\bullet}+\mathrm{e}_{\mathrm{cb}}^{-} & \rightarrow \mathrm{OH}^{-}
\end{aligned}
$$

The oxidation of organic pollutants $(\mathrm{R}-\mathrm{H})$ can take place by a direct reaction with holes (reaction (29)) or indirectly via hydroxyl radicals (reaction (30)) or free organic radicals (reaction $(31))[109,111]$ :

$$
\begin{aligned}
\mathrm{R}-\mathrm{H}+\mathrm{h}_{\mathrm{vb}}^{+} & \rightarrow \mathrm{R}^{+\bullet}+\text { degradation products } \\
\mathrm{R}-\mathrm{H}+\mathrm{OH}^{\bullet} & \rightarrow \mathrm{R}^{\bullet}+\mathrm{H}_{2} \mathrm{O} \\
\mathrm{R}^{\bullet}+\mathrm{O}_{2} & \rightarrow \mathrm{RO}_{2}^{\bullet} \rightarrow \mathrm{CO}_{2}+\text { intermediates }
\end{aligned}
$$

The hydroxyl radicals, generated under ambient conditions in this process, are nonselective powerful oxidant species capable of converting organic pollutants (toxic and nonbiodegradable) into relatively innocuous end products such as $\mathrm{CO}_{2}, \mathrm{H}_{2} \mathrm{O}$, and mineral acids [1].

3.1. Photocatalytic Activity of $\mathrm{TiO}_{2}$ under Sunlight. $\mathrm{TiO}_{2}$ semiconductor is mainly photoactive with artificial UV lamps that increase the electrical cost of the photocatalytic process. The sunlight is expected to improve the performance of $\mathrm{TiO}_{2}$ photocatalysis since it provides photons in the UV range (300-400 nm); also, doping $\mathrm{TiO}_{2}$ extends its photoresponse capacity towards the sunlight visible range $(400-700 \mathrm{~nm})$. The chemical surface alteration of $\mathrm{TiO}_{2}$ (when doped or photodoped with transition metals, noble metals, nonmetals, organic dye sensitization, and coupled semiconductors) modifies its electronic structure producing changes in the electron densities in the conduction band [113] which enhances the solar efficiency of $\mathrm{TiO}_{2}$ under solar irradiation and, hence, influences the mechanism of the photocatalytic process. Dopants can act as electron (or hole) traps preventing charge recombination, create an intermediate energy level introduced between the conduction band and the valence band, lead to band bend gap narrowing or expansion, and induce band bending or conduction band edge shifts which occur due to disruption of the lattice structure of the dopants and formation of surface oxygen vacancies [113-116]. Introduction of such energy levels in the band gap induces the red shift in the band gap transition and the visible light absorption through a charge transfer between a dopant and conduction band (or valence band) [112]. Nevertheless, these changes depend on the nature of dopants, synthesis methods, annealing process, dopant concentration, and dopant distribution $[11,112,113,117-120]$.

3.2. Influencing Parameters on the Degradation of Organic Compounds by $\mathrm{TiO}_{2}$ Solar Photocatalysis. Mineralization of organic compounds (conversion to $\mathrm{CO}_{2}$ and mineral acids) by the $\mathrm{TiO}_{2}$ solar photocatalytic process depends directly on the synthesis method of the catalyst [121-126], type of doping materials [11, 112, 113, 117-120], annealing temperature [127-131], catalyst load [132-135], pollutant concentration [136-139], and $\mathrm{pH}$ of the aqueous solution [140-142]. There are other parameters like reaction temperature, reactor configuration (geometry), reactor material, air sparging in the reactor solution, and the solar radiation intensity (solar concentration ratio) [143] that are important too in the $\mathrm{TiO}_{2}$ solar photocatalytic process. Nevertheless, these last factors contribute in less extension to the degradation of the pollutants compared to the most commonly studied such as catalyst load, pollutant concentration, and $\mathrm{pH}$ of the aqueous solution.

3.2.1. Effect of $\mathrm{TiO}_{2}$ Annealing Temperature. The influence of annealing temperature on the microstructure, surface morphology, and optical property of $\mathrm{TiO}_{2}$ particles, $\mathrm{TiO}_{2}$ 


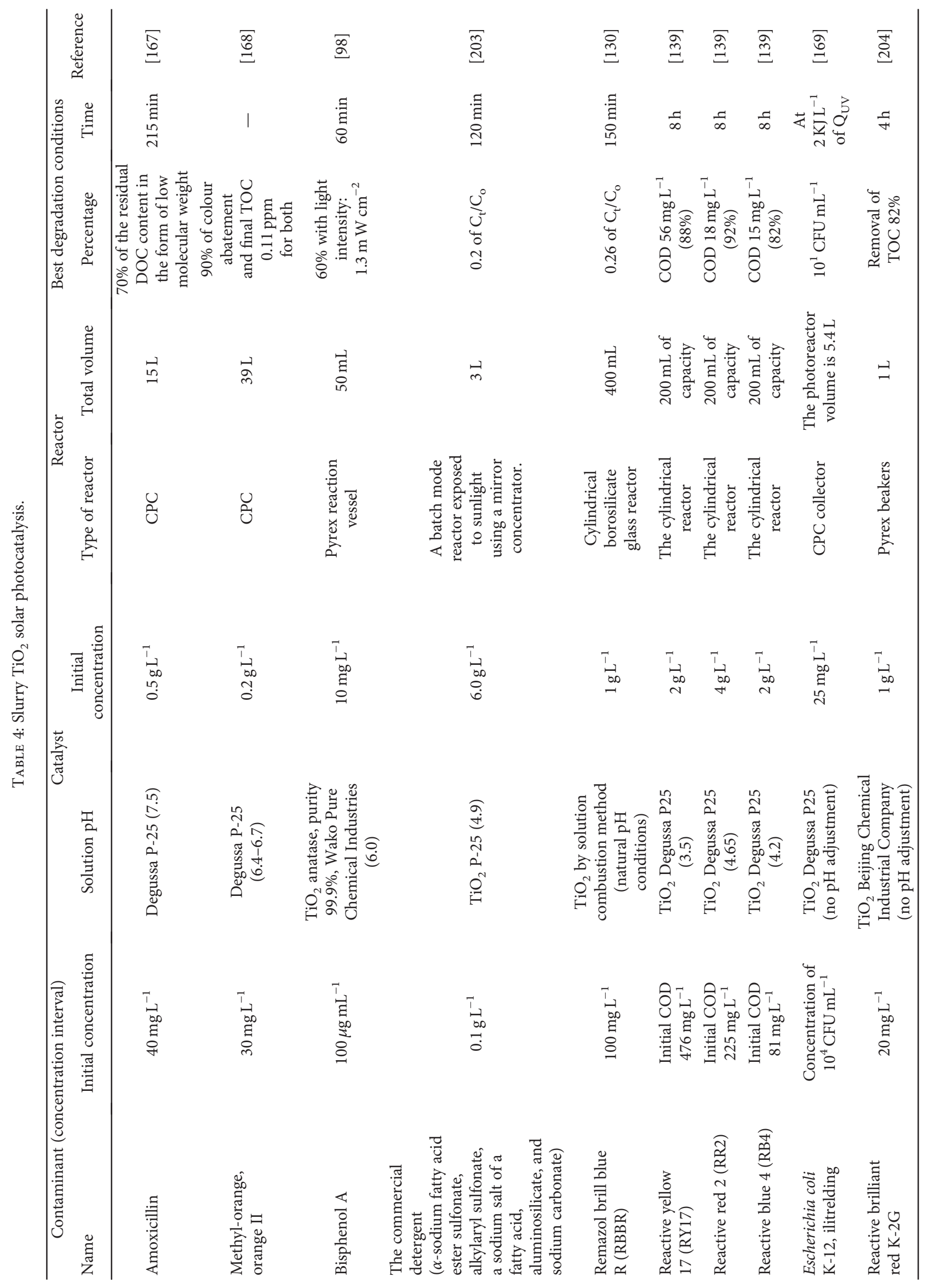




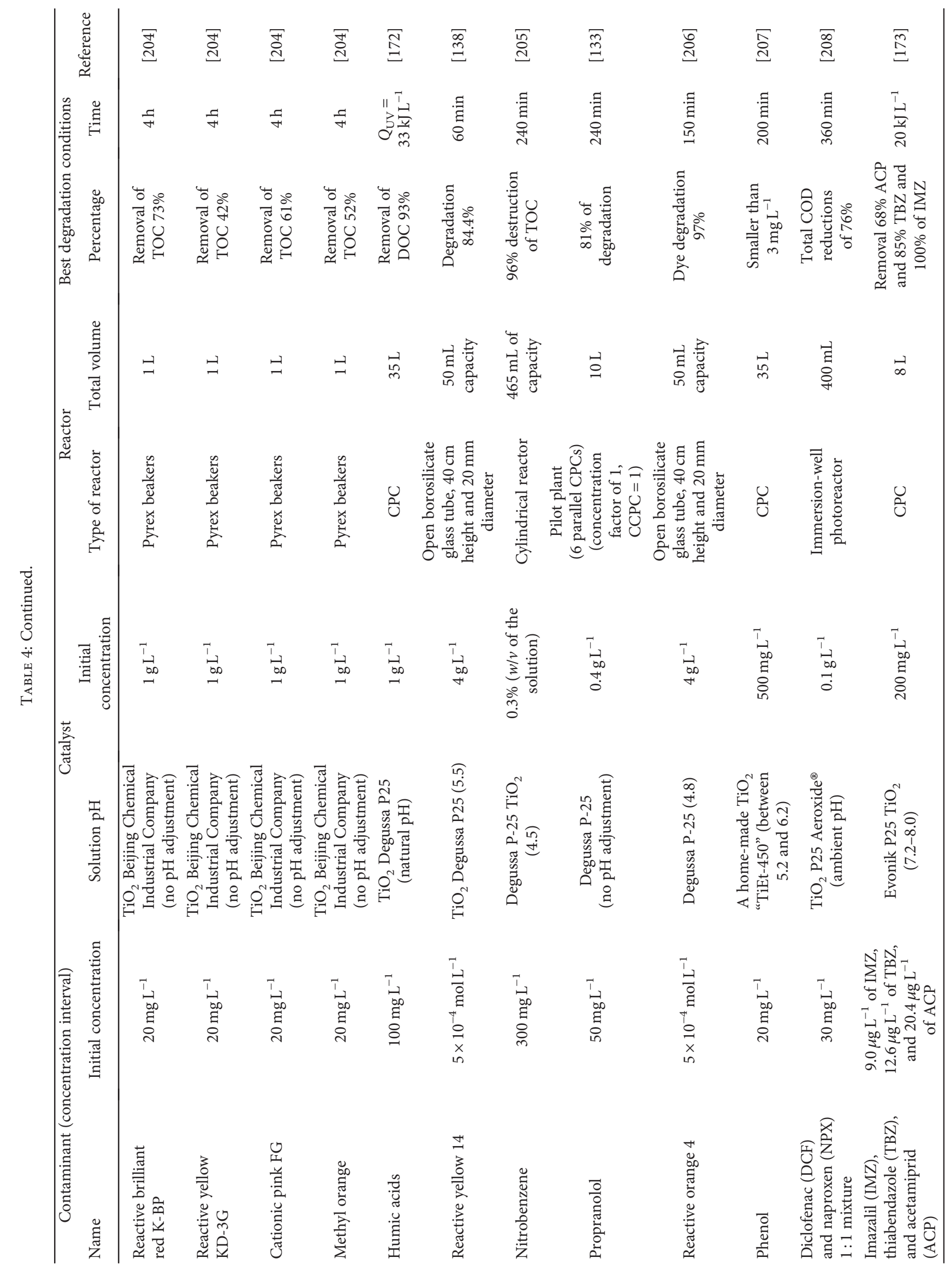




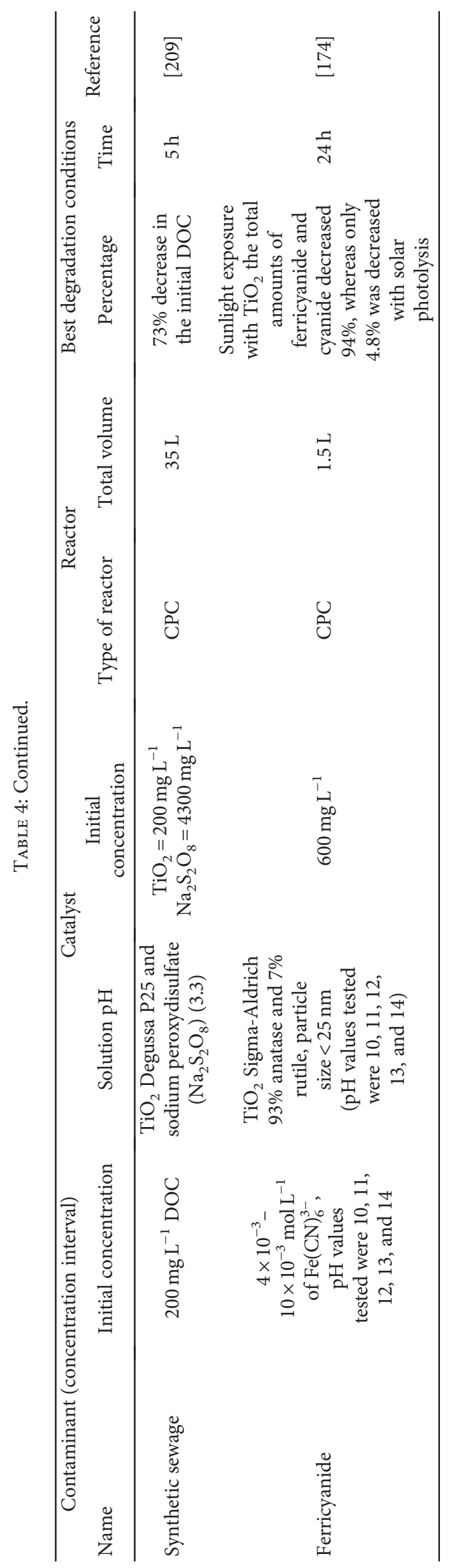




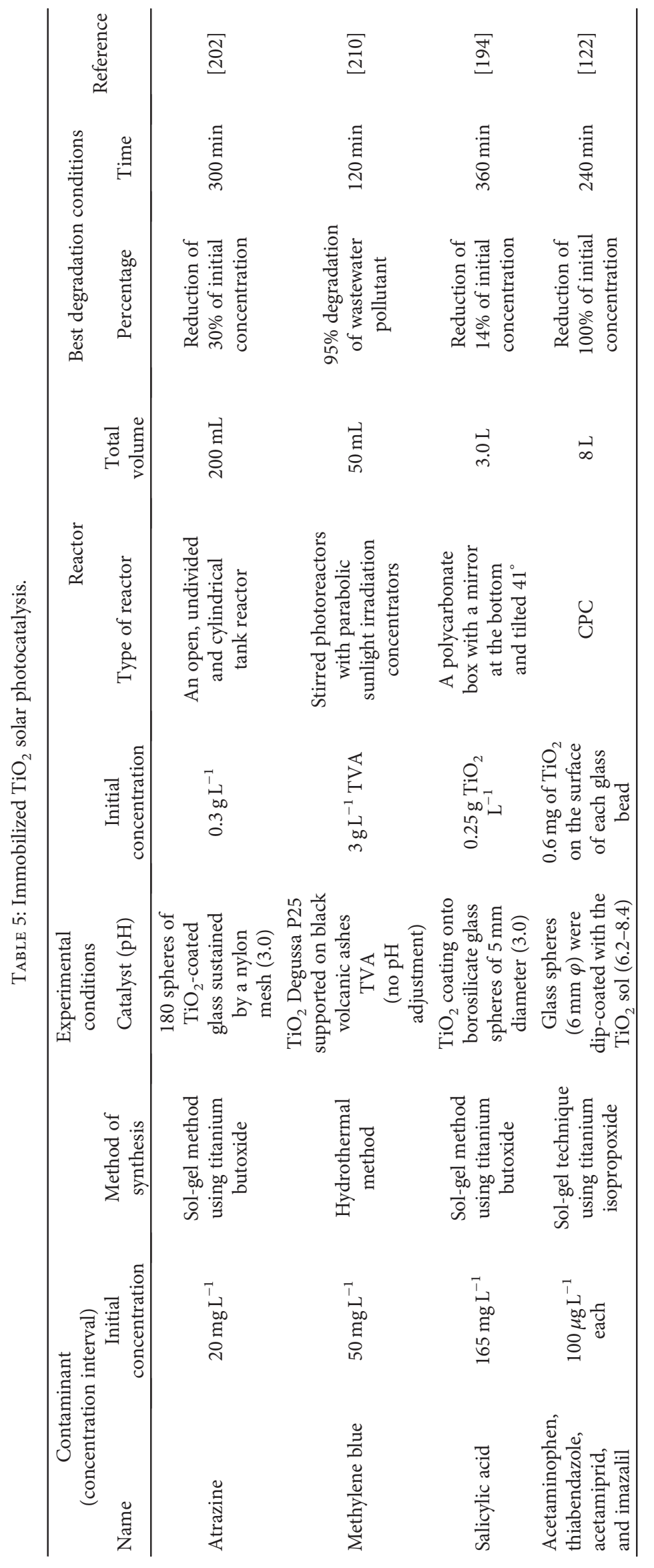




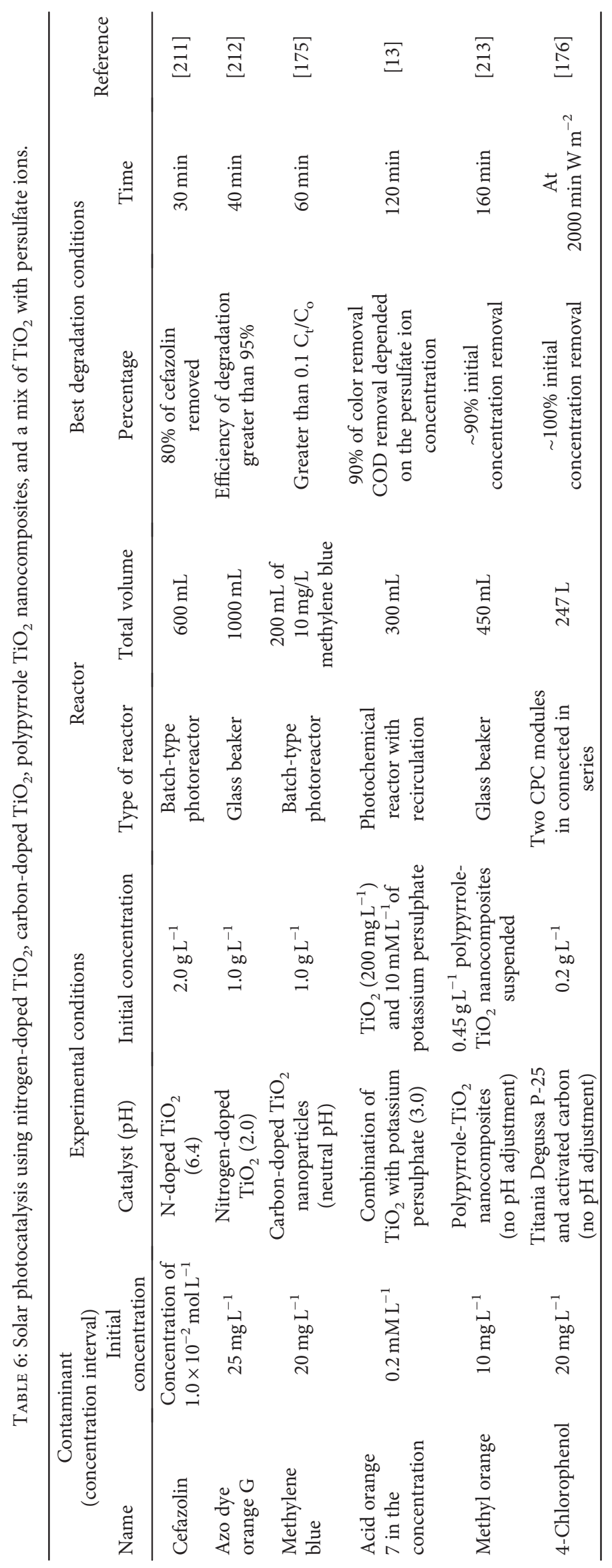




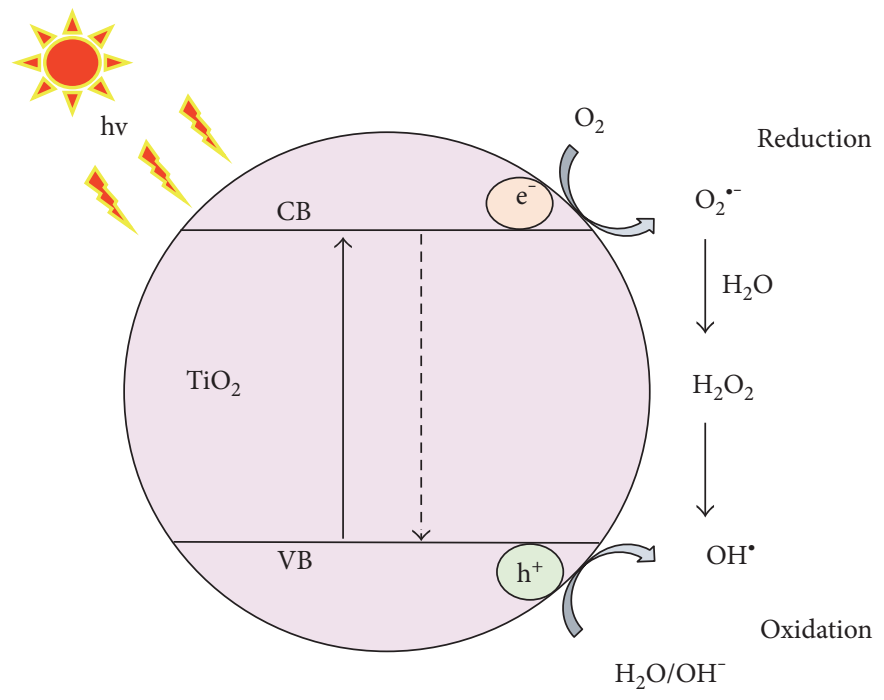

Scheme 1: Schematic representation of the photocatalysis mechanism.

nanoparticles, and $\mathrm{TiO}_{2}$ thin films strongly depends on the synthesis methods [144-149]. Three different phases of $\mathrm{TiO}_{2}$ have been reported which depend on the heat treatment like anatase, rutile, and brookite, anatase and rutile phases being commonly prepared [8, 9, 11, 145, 149]. It has been reported that anatase is more photoactive than rutile $[1,109,150,151]$; however, it has also been reported that synergistic effects of mixed phases of anatase and rutile enhances the photoactivity of the photocatalyst [152-155].

3.2.2. Influence of Catalyst Concentration. Catalyst load is an important factor that can affect the degradation rate of the organic pollutants; the optimum amount depends on the nature of the organic compound and on the geometry of the photoreactor [156-158]. When $\mathrm{TiO}_{2}$ concentration increases from 0 to certain values, a significant enhancement of efficiency is recorded for the elimination and mineralization of organics. However, there is a loading range in which either no significant changes are observed or even a decrease in the elimination of organic compounds happens. The number of active surface sites increases with $\mathrm{TiO}_{2}$ concentration until certain loading since light penetration decreases and aggregation of $\mathrm{TiO}_{2}$ particles increases at relative high catalyst loading [159]. It has been reported that $\mathrm{TiO}_{2}$ photocatalysis combined with ultrasound can be benefited [72, 97, 159, 160] due to different factors like (a) an increase in the catalyst surface area due to the aggregation action of ultrasound, which enhances the performance of the photocatalytic system [161]; (b) an improvement of mass transfer of organic compounds between the liquid phase and the $\mathrm{TiO}_{2}$ surface $[162,163]$; and (c) a reduction of charge recombination and promotion production of additional $\mathrm{OH}^{\bullet}$ due to the residual $\mathrm{H}_{2} \mathrm{O}_{2}$ generated $[162,163]$. Also, the continuous cleaning of the $\mathrm{TiO}_{2}$ surface by acoustic cavitation [164] might also have some role in modifying the photocatalytic rate. Tables 4-6 show that different amounts of catalyst ranging from $10 \mathrm{mg} \mathrm{L}^{-1}$ to $4 \mathrm{gL}^{-1}$ yielded different degrees of organic degradation during the photocatalytic oxidation process under the experimental conditions stated.
3.2.3. Influence of Initial Pollutant Concentration and $p H$ of the Solution. The initial concentration of the organic compounds at constant $\mathrm{pH}$ and different initial $\mathrm{pH}$ of the solution are also important factors that affect the degradation rate of the organic pollutants and the efficiency of the photocatalytic oxidation process.

As the initial concentration of organics increases, the photocatalytic efficiency decreases due to a decrease of the reaction rate, which is attributed to a decrease in the number of photons and $\mathrm{TiO}_{2}$ particles available, since the number of organic molecules adsorbed onto the catalyst may block catalyst activation. Also, the initial $\mathrm{pH}$ of the solution influences the rate of the degradation process. It has been reported that the adsorption of the organic compounds onto the $\mathrm{TiO}_{2}$ surface is affected by the $\mathrm{pH}$ of the solution $[97,160]$. The pollutant and thus the rates of degradation will be maximum near the point of zero charge (pzc) of the catalyst [164]. The pzc of $\mathrm{TiO}_{2}$ surface is at $\mathrm{pH}_{\mathrm{pzc}}$ between 6.25 and $7.1[1,165,166]$, depending on the ionic strength [166]. Tables 4,5 , and 6 show that different initial pollutant concentration and solution $\mathrm{pH}$ were used to degrade different organics during the photocatalytic oxidation process under the experimental conditions stated. Most of the experiments were carried out in the $\mathrm{pH}$ range of 2.0-14, and some were with no $\mathrm{pH}$ control, as depicted on Tables 4-6.

3.3. Organic Matter Degradation by $\mathrm{TiO}_{2}$ Solar Photocatalysis. The sunlight can be used efficiently in the $\mathrm{TiO}_{2}$ photocatalytic process with the use of solar reactors that concentrate the solar irradiation. Thereby, $\mathrm{TiO}_{2}$ solar photocatalysis is cost-effective and environmentally friendly alternative.

The use of CPC solar photoreactors was shown to be effective for $\mathrm{TiO}_{2}$ solar photocatalytic degradation of several organic contaminants such as antibiotics [167], azo dyes [168], water disinfection [169, 170], pesticides $[8,171]$, humic acids [172], agro-food industry effluents [173], and ferricyanide [174]. 
Pereira and coworkers [167] studied the $\mathrm{TiO}_{2}$ solar photocatalytic degradation of the antibiotic amoxicillin in aqueous solutions at neutral conditions ( $\mathrm{pH}$ 7.5). These authors reported that the solar UV radiation alone was unable to attack the antibiotic molecules during the same treatment period as in the $\mathrm{TiO}_{2}$ solar photocatalysis. They observed that the antibiotic concentration was reduced from 40 to $3.1 \mathrm{mg} \mathrm{L}^{-1}$ (at $4.6 \mathrm{~kJ}_{\mathrm{UV}} \mathrm{L}^{-1}$ of UV accumulated energy in the CPC) by $\mathrm{TiO}_{2}$ solar photocatalysis which led to a considerable reduction of the antibacterial activity with $71 \%$ mineralization at the end of the treatment. They attributed such findings mainly to hydroxyl radicals, although singlet oxygen also played an important role in the antibiotic amoxicillin self-photosensitization under UV/visible solar light.

The combination of $\mathrm{TiO}_{2}$ solar photocatalysis with $\mathrm{H}_{2} \mathrm{O}_{2}$ and persulfate ions $\left(\mathrm{S}_{2} \mathrm{O}_{8}^{2-}\right)$, as electron acceptors, for the degradation of azo dyes using CPC reactors was studied [168]. It was reported that the presence of hydrogen peroxide did not affect appreciably the photodegradation rate of methyl-orange but the presence of $\mathrm{S}_{2} \mathrm{O}_{8}^{2-}$ was strongly beneficial. It was also reported that the presence of both $\mathrm{H}_{2} \mathrm{O}_{2}$ and $\mathrm{S}_{2} \mathrm{O}_{8}^{2-}$ was always beneficial for orange-II degradation. Complete decolourization was achieved in a few hours for both dyes but mineralization occurred after longer times with the formation of $\mathrm{CO}_{2}, \mathrm{NO}_{3}^{-}$, and $\mathrm{SO}_{4}^{2-}$ ions. JiménezTototzintle and coworkers [173] added $\mathrm{H}_{2} \mathrm{O}_{2}$ to the solar photocatalytic CPC reactor to treat pesticides (biorecalcitrant compounds) for improving supported $\mathrm{TiO}_{2}$ photocatalysis efficiency. It was reported that nearly complete removal of pesticides was acquired avoiding expensive separation of $\mathrm{TiO}_{2}$ slurries from treated wastewater.

Water disinfection by $\mathrm{TiO}_{2}$ solar photocatalysis in a solar reactor was also studied in simulated wastewater containing E. coli K-12 [169] and urban effluent contaminated with E. coli and F. solani spores [170]. Fernández et al. [169] observed that bactericidal deactivation by sunlight in a CPC solar collector occurred with and without catalyst. The total photocatalytic deactivation of pure E. coli suspensions was a consequence of the combined effect of sunlight and the oxidant species generated in the $\mathrm{TiO}_{2}$ in suspensions and or by supported $\mathrm{TiO}_{2}$. The slurry $\mathrm{TiO}_{2}$ was more efficient for bacteria deactivation than the supported $\mathrm{TiO}_{2}$ in the solar photocatalytic process. García-Fernández and collaborators [170] reported that the temperature and the dissolved oxygen, the most commonly used electron acceptor, were key factors for water disinfection. Thus, changes in temperature of photocatalytic reactors for water disinfection should be considered to evaluate the efficiency of the process. Also, air sparging caused improvements in the bacterial and spore photocatalytic inactivation, which was specifically manifested in F. solani spores. This was in line with the important role of dissolved oxygen in photocatalytic water disinfection.

Arellano and Martínez [174] investigated the effects of $\mathrm{pH}$ on the degradation of aqueous ferricyanide by photolysis and photocatalysis in the solar CPC reactor. These authors revealed that upon sunlight exposure, the conversion of ferricyanide to ferrocyanide and the reverse reaction depended strongly on the $\mathrm{pH}$ of the solution whether or not the $\mathrm{TiO}_{2}$ catalyst was present. Thus, the $\mathrm{pH}$ of the solution dictated the type of redox reaction that would proceed under illumination. Additionally, the extent of the heterogeneous photocatalytic degradation of ferricyanide was influenced by $\mathrm{pH}$, but the initial concentration of ferricyanide did not affect its degradation.

Tables 4 and 5 summarize the degradation of several organics by $\mathrm{TiO}_{2}$ solar photocatalysis in which suspended or immobilized $\mathrm{TiO}_{2}$ was used, respectively. As can be seen, the degradation and mineralization were taken place in several solar reactors under different experimental conditions in which the oxidation of the organic matter with time was followed by parameters like DOC, TOC, COD, and organic concentration decrease. Also, the efficiency of the $\mathrm{TiO}_{2}$ solar photocatalysis depended on the suspended or immobilized $\mathrm{TiO}_{2}$ catalyst phase, nature of organic contaminant, solution $\mathrm{pH}$, reaction time, and the initial concentration of the organics. Thus, these studies have shown that sunlight was used efficiently in the $\mathrm{TiO}_{2}$ solar photocatalytic process acquiring high oxidation yields.

In order to take advantage of the solar photons in the visible range $(400-700 \mathrm{~nm})$ and make the degradation process more efficient under the sunlight, some studies were conducted using doped $\mathrm{TiO}_{2}$ catalyst, as shown in Table 6. Solar photocatalysis using nitrogen-doped $\mathrm{TiO}_{2}$, carbon-doped $\mathrm{TiO}_{2}$, polypyrrole- $\mathrm{TiO}_{2}$ nanocomposites, and $\mathrm{TiO}_{2}$ with persulfate ion addition were conducted to oxidize diverse organics. These studies have shown better performance of the solar photocatalytic process using doped $\mathrm{TiO}_{2}$ catalyst and higher organic mineralization. The efficiency of the solar photocatalysis using carbon-doped $\mathrm{TiO}_{2}$ was ascribed to the presence of oxygen vacancy state between the valence and the conduction bands because of the formation of $\mathrm{Ti}^{3+}$ species in the as-synthesized carbon-doped titania [175]. Herrmann and coworkers [176] degraded the 4-chlorophenol compound (4-CP) by solar photocatalysis using carbon-doped $\mathrm{TiO}_{2}$. These authors reported that the addition of a commercial activated carbon to titania under UV irradiation could have induced a substantial synergy effect in the photoefficiency of the photocatalyst. It had been explained by an important adsorption of 4-CP on activated carbon (AC) followed by a mass transfer to photoactive titania. According to these authors, such transfer occurred mainly via a spillover of 4-CP through the contact surface between $\mathrm{AC}$ and $\mathrm{TiO}_{2}$. This interface was spontaneously created by a mere mixture of both phases in suspension. The simple mixture of the two solids had permitted to avoid a preparation procedure which would have modified the surface of both constituents and prevented a direct comparison from their initial surface state. These authors stated that the synergy effect of the AC could be extrapolated to a large solar pilot plant scale, working in the near UV fringe of sunlight.

\section{Scaling-Up of the Solar Processes}

The application of solar-powered photoreactors for wastewater treatment represent an environmental alternative specially for regions receiving strong sunlight throughout the year. The solar photoreactors decrease the operating, capital, and maintenance costs associated to photocatalytic 
reaction systems that are powered with UV lamps. Thus, an appropriate design of solar photoreactors is important to ensure efficient conversion of incident photons to oxidant reactive species such as $\mathrm{OH}^{\bullet}$ and holes, among some others [177]. According to Sagawe et al., several parameters need to be addressed for the design of field-scale photoreactors such as pollutant concentration (COD initial load), volumetric flow rate, light intensity, and solar irradiation area; also, the concentration of dissolved oxygen in water, in equilibrium with atmospheric air, defines the limits of all practical oxidizing processes for removing pollutants in photocatalytic reactors [178].

The variability in both the composition and concentration of real wastewater effluents in addition to the solar photon flux variation during the degradation process makes more difficult the field-scale reactors and also increases the cost. Soares et al. made an economic assessment using UVA-vis radiation (solar light) or UVC radiation (lamps) based on the operation variables obtained for the treatment of $30,240 \mathrm{~m}^{3}$ per day of a textile wastewater after a biological preoxidation process (to achieve the values required by German regulations for discharge into water bodies); from this study, the following conclusions were withdrawn: (a) at acidic $\mathrm{pH}$ values, the addition of iron to the UVC/ $\mathrm{H}_{2} \mathrm{O}_{2}$ reaction enhanced the decolourisation rates, resulting in a lower treatment cost when compared to neutral $\mathrm{pH}$ conditions; (b) the $\mathrm{UVC} / \mathrm{H}_{2} \mathrm{O}_{2}$ system at natural wastewater $\mathrm{pH}$ is cheaper than at acid $\mathrm{pH}$, mainly due to the need for acids and bases; (c) the use of solar radiation (UVA-vis) increases the treatment costs, mainly due to an increase in the capital spending associated with CPC; (d) the addition of oxalic acid to the photo-Fenton reaction decreases the capital spending (high reaction rates), but the cost of consumables increases significantly, making the treatment more costly; and (e) the photoFenton system mediated by ferrioxalate at near neutral $\mathrm{pH}$ using solar radiation is the most costly treatment process, due to the low decolourization rates and high consumption of reactants, especially oxalic acid [179].

Silva et al. proposed a methodology for the treatment of landfill leachates, after aerobic lagooning and adjusted at pilot scale. Such methodology involved an aerobic activated sludge biological preoxidation, a coagulation/sedimentation step and a photooxidation through a photo-Fenton reaction combining solar and artificial light [108]. These authors reported that the $\mathrm{H}_{2} \mathrm{O}_{2}$ was the reactant that most contributed to the final treatment cost $(\sim 42 \%)$, while the sulphuric acid and the ferrous iron were the chemicals that contributed less $(\sim 1 \%)$. Finally, the combination of solar and artificial radiation, taking into account the energetic needs throughout the year, showed to be the best alternative to treat $100 \mathrm{~m}^{3} /$ day of leachate targeting a COD value lesser than $150 \mathrm{ppm}$ and $1000 \mathrm{mg} \mathrm{O}_{2} / \mathrm{L}$.

Jordá et al. performed an economic evaluation of the photo-Fenton process to degrade paracetamol in water to form biodegradable reaction intermediates which can be finally removed with a downstream biological treatment [180]. These authors observed that the key feature was to find the shortest chemical treatment time necessary to reach a sufficiently high biodegradability of the treated water which minimized the cost of the overall process.

A comparison of $\mathrm{TiO}_{2}$ solar photocatalysis and solar photo-Fenton for the treatment of pesticides from industrial wastewater was carried out to assess the viability of solar heterogeneous photocatalysis $\left(\mathrm{UV} / \mathrm{TiO}_{2}\right)$ and photoFenton (UV/ $/ \mathrm{Fe}^{2+} / \mathrm{H}_{2} \mathrm{O}_{2}$ ) for the treatment of agrochemical industrial wastewater at lab scale using CPC reactors. Also, the operational conditions, kinetics, and treatment costs were estimated [181]. Their results showed that the cost of photo-Fenton process was more economical than $\left(\mathrm{UV} / \mathrm{TiO}_{2}\right)$ photocatalysis and $\left(\mathrm{UV} / \mathrm{TiO}_{2} / \mathrm{H}_{2} \mathrm{O}_{2}\right)$ processes. In addition, the maximum COD removal (90.7\%) by photo-Fenton process was higher than that obtained by $\mathrm{TiO}_{2}$ photocatalysis (79.6\%) and the cost was 34.8\% more economical, which was considered the best solution concerning the process performance. Finally, these authors observed that the variation of operating costs mainly depends on the type and dosage of chemicals.

Zapata et al. developed a strategy targeting the design of an industrial scale combined solar photo-Fenton/aerobic biological system for the decontamination of commercial pesticides [182] using CPC reactors. These authors recommended that for adequate design of this type of treatment, a detailed study should be done for each particular case using different analytical tools and bioassays, mainly dissolved organic carbon, chemical oxygen demand, toxicity, and biodegradability. It was demonstrated that the $\mathrm{H}_{2} \mathrm{O}_{2}$ dose was a critical parameter for the design and control of operation of the combined system. It also remarked the importance of the wide difference in efficiency found in the biological treatment stage when the integrated system was scaled up. Based on their results, these authors highlighted how decisive and restrictive (for the treatment of very specific and variable wastewater) start-up and growth could be in implementing a new biological reactor, especially when the biotreatment is performed in an immobilized biomass reactor which is much more resistant than a conventional sequencing batch reactor. Their observations highlighted the limitations of the results obtained in small laboratory devices and working with model wastewaters to design a proper treatment [182].

Chong et al. [183] published an interesting review on the research and development progresses of engineered photocatalysts, photoreactor systems, and the process optimizations and modellings of the photooxidation processes for water treatment. These authors mentioned several key technical constraints ranging from catalyst development to reactor design and process optimization that have to be addressed, such as (a) catalyst improvement for a high photoefficiency that can utilize wider solar spectra, (b) catalyst immobilization strategy to provide a cost-effective solid/liquid separation, (c) effective design of solar photoreactors because of the low efficacy design of current solar collecting technology $(0.04 \%$ capture of original solar photons), and (d) the need of a large scale, solar-driven, photocatalytic treatment process with high efficacy and low site area requirements with different possible pilot plant configurations. 


\section{Concluding Remarks}

Solar-driven photocatalysis, as in the processes of solar photo-Fenton and $\mathrm{TiO}_{2}$ solar photocatalysis, is an environmentally friendly alternative mainly because the use of electricity can be decreased/avoided. Indeed, the solardriven processes can be driven by a photovoltaic system when scale up to a pilot plant or solar plant to decrease the costs associated with electricity consumption. These two solar photocatalytic processes represent powerful tools for removing organic pollutants from aqueous solution. Total mineralization of diverse organics has been achieved under different experimental conditions. Mineralization of organics with these solar processes depends on the nature of the contaminants and on other parameters such as solution $\mathrm{pH}$, catalyst amount, and initial concentration of organics. Thus, to yield high mineralization, each process requires optimal experimental conditions of such parameters. However, in order to take advantage of the solar light in these solar photocatalytic technologies, photoreactors need to be specifically designed for these purposes. The literature reports the use of different types of reactors to treat wastewater by these solar-driven processes, but some are difficult to scale up.

\section{Conflicts of Interest}

The authors declare that they have no conflicts of interest.

\section{Acknowledgments}

The authors are grateful to the Ministry of Science and Technology (CONACyT), Mexico, for the grant given to A. G. Gutierrez-Mata and S. Velazquez-Martínez.

\section{References}

[1] M. R. Hoffmann, S. Martin, W. Choi, and D. W. Bahnemann, "Environmental applications of semiconductor photocatalysis," Chemical Reviews, vol. 95, pp. 69-96, 1995.

[2] N. Klamerth, L. Rizzo, S. Malato, M. I. Maldonado, A. Agüera, and A. R. Fernández-Alba, "Degradation of fifteen emerging contaminants at $\mu \mathrm{gL}-1$ initial concentrations by mild solar photo-Fenton in MWTP effluents," Water Research, vol. 44, pp. 545-554, 2010.

[3] N. Miranda-García, S. Suárez, B. Sánchez, J. M. Coronado, S. Malato, and M. I. Maldonado, "Photocatalytic degradation of emerging contaminants in municipal wastewater treatment plant effluents using immobilized $\mathrm{TiO} 2$ in a solar pilot plant," Applied Catalysis B: Environmental, vol. 103, pp. 294-301, 2011.

[4] M. Hincapié, M. I. Maldonado, I. Oller et al., "Solar photocatalytic degradation and detoxification of EU priority substances," Catalysis Today, vol. 101, pp. 203-210, 2005.

[5] C. Lizama-Bahena, A. Álvarez-Gallegos, J. A. Hernandez, and S. Silva-Martinez, "Elimination of bio-refractory chlorinated herbicides like atrazine, alachlor, and chlorbromuron from aqueous effluents by Fenton, electro-Fenton, and peroxicoagulation methods," Desalination and Water Treatment, vol. 55, pp. 3683-3693, 2015.
[6] S. Malato, J. Blanco, J. Cáceres, A. R. Fernández-Alba, A. Agüera, and A. Rodríguez, "Photocatalytic treatment of water-soluble pesticides by photo-Fenton and $\mathrm{TiO} 2$ using solar energy," Catalysis Today, vol. 76, pp. 209-220, 2002.

[7] S. S. Martínez and C. L. Bahena, "Chlorbromuron urea herbicide removal by electro-Fenton reaction in aqueous effluents," Water Research, vol. 43, pp. 33-40, 2009.

[8] C. A. Pineda Arellano, A. J. González, S. S. Martínez, I. Salgado-Tránsito, and C. P. Franco, "Enhanced mineralization of atrazine by means of photodegradation processes using solar energy at pilot plant scale," Journal of Photochemistry and Photobiology A: Chemistry, vol. 272, pp. 21-27, 2013.

[9] J. Radjenović, C. Sirtori, M. Petrović, D. Barceló, and S. Malato, "Solar photocatalytic degradation of persistent pharmaceuticals at pilot-scale: kinetics and characterization of major intermediate products," Applied Catalysis B: Environmental, vol. 89, pp. 255-264, 2009.

[10] J. M. Chacó, M. T. Leal, M. Sánchez, and E. R. Bandala, "Solar photocatalytic degradation of azo-dyes by photo-Fenton process," Dyes and Pigments, vol. 69, pp. 144-150, 2006.

[11] D. J. R. Gutiérrez, N. R. Mathews, and S. S. Martínez, "Photocatalytic activity enhancement of $\mathrm{TiO} 2$ thin films with silver doping under visible light," Journal of Photochemistry and Photobiology A: Chemistry, vol. 262, pp. 57-63, 2013.

[12] R. Jaimes, C. A. Pineda, A. A. Álvarez, A. E. Jiménez, and S. Silva, "H 2 O 2 -assisted TiO 2 generation during the photoelectrocatalytic process to decompose the acid green textile dye by Fenton reaction," Journal of Photochemistry and Photobiology A: Chemistry, vol. 305, pp. 51-59, 2015.

[13] S. F. Villanueva and S. S. Martínez, "TiO2-assisted degradation of acid orange 7 textile dye under solar light," Solar Energy Materials \& Solar Cells, vol. 91, pp. 1492-1495, 2007.

[14] R. B. Domínguez-Espíndola, J. C. Varia, A. Álvarez-Gallegos, M. L. Ortiz-Hernández, J. L. Peña-Camacho, and S. SilvaMartínez, "Photoelectrocatalytic inactivation of fecal coliform bacteria in urban wastewater using nanoparticulated films of TiO 2 and $\mathrm{TiO}$ 2/Ag," Environmental Technology, vol. 38, pp. 1-9, 2016.

[15] A. G. Rincón and C. Pulgarin, "Absence of E. coli regrowth after $\mathrm{Fe} 3+$ and $\mathrm{TiO} 2$ solar photoassisted disinfection of water in CPC solar photoreactor," Catalysis Today, vol. 124, pp. 204-214, 2007.

[16] D. Spuhler, J. Andrés Rengifo-Herrera, and C. Pulgarin, "The effect of $\mathrm{Fe} 2+, \mathrm{Fe} 3+, \mathrm{H} 2 \mathrm{O} 2$ and the photo-Fenton reagent at near neutral $\mathrm{pH}$ on the solar disinfection (SODIS) at low temperatures of water containing Escherichia coli K12," Applied Catalysis B: Environmental, vol. 96, pp. 126-141, 2010.

[17] F. Haber and J. Weiss, "The catalytic decomposition of hydrogen peroxide by iron salts," Proceedings of the Royal Society of London A: Mathematical, Physical and Engineering Sciences, vol. 147, pp. 332-351, 1934.

[18] D. I. Metelitsa, "Mechanisms of the hydroxylation of aromatic compounds," Russian Chemical Reviews, vol. 40, pp. 563-580, 1971.

[19] J. J. Pignatello, E. Oliveros, and A. MacKay, "Advanced oxidation processes for organic contaminant destruction based on the Fenton reaction and related chemistry," Critical Reviews in Environmental Science and Technology, vol. 36, pp. 1-84, 2006. 
[20] H. Christensen, K. Sehested, and H. Corfitzen, "Reactions of hydroxyl radicals with hydrogen peroxide at ambient and elevated temperatures," The Journal of Physical Chemistry, vol. 86, pp. 1588-1590, 1982.

[21] G. G. Jayson, J. P. Keene, D. A. Stirling, and A. J. Swallow, "Pulse-radiolysis study of some unstable complexes of iron," Transactions of the Faraday Society, vol. 65, p. 2453, 1969.

[22] W. H. Koppenol, J. Butler, and J. W. Van Leeuwen, "The Haber-Weiss cycle," Photochemistry and Photobiology, vol. 28, pp. 655-660, 1978.

[23] W. H. Koppenol and W. H. Koppenol, "The Haber-Weiss cycle - 70 years later the Haber-Weiss cycle - 70 years later," Redox Report: Communications in Free Radical Research, pp. 229-234, 2001.

[24] J. D. Rush and B. H. J. Bielski, "Pulse radiolysis studies of alkaline iron(III) and iron(VI) solutions. Observation of transient iron complexes with intermediate oxidation states," The Journal of Physical Chemistry, vol. 89, pp. 5062-5066, 1985.

[25] Z. Stuglik and Z. PawełZagórski, "Pulse radiolysis of neutral iron(II) solutions: oxidation of ferrous ions by OH radicals," Radiation Physics and Chemistry, vol. 17, pp. 229-233, 1981.

[26] C. Walling and A. Goosen, "Mechanism of the ferric ion catalyzed decomposition of hydrogen peroxide. Effect of organic substrates," Journal of the American Chemical Society, vol. 95, pp. 2987-2991, 1973.

[27] J. De Laat and H. Gallard, "Catalytic decomposition of hydrogen peroxide by Fe ( III ) in homogeneous aqueous solution : mechanism and kinetic modeling," Environmental Science \& Technology, vol. 33, pp. 2726-2732, 1999.

[28] H. Gallard, J. De Laat, and B. Legube, "Spectrophotometric study of the formation of iron(III)-hydroperoxy complexes in homogeneous aqueous solutions," Water Research, vol. 33, pp. 2929-2936, 1999.

[29] H. Gallard and J. D. E. Laat, "Kinetic modelling of Fe (III)/ $\mathrm{H} 2 \mathrm{O} 2$ oxidation reactions in dilute aqueous solution using atrazine as a model organic compound," Water Research, vol. 34, pp. 3107-3116, 2000.

[30] R. Milburn and W. Vosburgh, "Spectrophotometric study of the hydrolysis of iron(II1) ion," Journal of the American Chemical Society, vol. 77, pp. 1352-1355, 1955.

[31] R. G. Zepp, B. C. Faust, and J. Hoigne, "Hydroxyl radical formation in aqueous reactions ( $\mathrm{pH} 3-8$ ) of iron(II) with hydrogen peroxide: the photo-Fenton reaction," Environmental Science \& Technology, vol. 26, pp. 313-319, 1992.

[32] Y. Zuo and J. Holgne, "Formation of hydrogen peroxide and depletion of oxalic acid in atmospheric water by photolysis of iron(III)-oxalato complexes," Environmental Science \& Technology, vol. 26, pp. 1014-1022, 1992.

[33] Y. H. Huang, Y. J. Huang, H. C. Tsai, and H. T. Chen, "Degradation of phenol using low concentration of ferric ions by the photo-Fenton process," Journal of the Taiwan Institute of Chemical Engineers, vol. 41, pp. 699-704, 2010.

[34] H. Kusic, N. Koprivanac, and A. L. Bozic, "Treatment of chlorophenols in water matrix by UV/ferri-oxalate system: part II. Degradation mechanisms and ecological parameters evaluation," Desalination, vol. 280, pp. 208-216, 2011.

[35] D. R. Manenti, P. A. Soares, A. N. Módenes et al., "Insights into solar photo-Fenton process using iron(III)-organic ligand complexes applied to real textile wastewater treatment," Chemical Engineering Journal, vol. 266, pp. 203-212, 2015.
[36] O. Ganzenko, D. Huguenot, E. D. van Hullebusch, G. Esposito, and M. A. Oturan, "Electrochemical advanced oxidation and biological processes for wastewater treatment: a review of the combined approaches," Environmental Science and Pollution Research, vol. 21, no. 14, pp. 8493-8524, 2014.

[37] Z. Qiang, J.-H. Chang, and C.-P. Huang, "Electrochemical regeneration of $\mathrm{Fe} 2+$ in Fenton oxidation processes," Water Research, vol. 37, pp. 1308-1319, 2003.

[38] E. Brillas, I. Sirés, and M. A. Oturan, "Electro-Fenton process and related electrochemical technologies based on Fenton's reaction Chemistry," Chemical Reviews, vol. 109, pp. 65706631, 2009.

[39] H. Nakagawa, S. Takagi, and J. Maekawa, "Fered-Fenton process for the degradation of 1,4-dioxane with an activated carbon electrode: a kinetic model including active radicals," Chemical Engineering Journal, vol. 296, pp. 398405, 2016.

[40] M. Arienzo, J. Chiarenzelli, R. Scrudato, J. Pagano, L. Falanga, and B. Connor, "Iron-mediated reactions of polychlorinated biphenyls in electrochemical peroxidation process (ECP)," Chemosphere, vol. 44, pp. 1339-1346, 2001.

[41] K. Pratap and A. T. Lemley, "Electrochemical peroxide treatment of aqueous herbicide solutions," Journal of Agricultural and Food Chemistry, vol. 42, pp. 209-215, 1994.

[42] D. A. Saltmiras and A. T. Lemley, "Degradation of ethylene thiourea (ETU) with three Fenton treatment processes," Journal of Agricultural and Food Chemistry, vol. 48, pp. 6149-6157, 2000.

[43] M. Skoumal, R. M. Rodríguez, P. L. Cabot et al., "Electro-Fenton, UVA photoelectro-Fenton and solar photoelectroFenton degradation of the drug ibuprofen in acid aqueous medium using platinum and boron-doped diamond anodes," Electrochimica Acta, vol. 54, pp. 2077-2085, 2009.

[44] E. Brillas, B. Boye, and M. M. Dieng, "Peroxi-coagulation and photoperoxi-coagulation treatments of the herbicide 4chlorophenoxyacetic acid in aqueous medium using an oxygen-diffusion cathode," Journal of the Electrochemical Society, vol. 150, pp. E148-E154, 2003.

[45] E. Brillas and J. Casado, "Aniline degradation by electroFenton ${ }^{\circledR}$ and peroxi-coagulation processes using a flow reactor for wastewater treatment," Chemosphere, vol. 47, pp. 241-248, 2002.

[46] A. Alvarez-Gallegos and D. Pletcher, "The removal of low level organics via hydrogen peroxide formed in a reticulated vitreous carbon cathode cell, part 1 . The electrosynthesis of hydrogen peroxide in aqueous acidic solutions," Electrochimica Acta, vol. 44, pp. 853-861, 1998.

[47] X. Yu, M. Zhou, G. Ren, and L. Ma, "A novel dual gas diffusion electrodes system for efficient hydrogen peroxide generation used in electro-Fenton," Chemical Engineering Journal, vol. 263, pp. 92-100, 2015.

[48] A. Wang, Y. Y. Li, and J. Ru, "The mechanism and application of the electro-Fenton process for azo dye acid red 14 degradation using an activated carbon fibre felt cathode," Journal of Chemical Technology and Biotechnology, vol. 85, pp. 1463-1470, 2010.

[49] F. Yu, M. Zhou, and X. Yu, "Cost-effective electro-Fenton using modified graphite felt that dramatically enhanced on $\mathrm{H} 2 \mathrm{O} 2$ electro-generation without external aeration," Electrochimica Acta, vol. 163, pp. 182-189, 2015. 
[50] E. Mousset, Z. Wang, J. Hammaker, and O. Lefebvre, "Physico-chemical properties of pristine graphene and its performance as electrode material for electro-Fenton treatment of wastewater," Electrochimica Acta, vol. 214, pp. 217-230, 2016.

[51] K. Cruz-González, O. Torres-López, A. García-León et al., "Determination of optimum operating parameters for acid yellow 36 decolorization by electro-Fenton process using BDD cathode," Chemical Engineering Journal, vol. 160, pp. 199-206, 2010.

[52] A. Durán, J. M. Monteagudo, and E. Amores, "Solar photoFenton degradation of reactive blue 4 in a CPC reactor," Applied Catalysis B: Environmental, vol. 80, pp. 42-50, 2008.

[53] L. I. Doumic, P. A. Soares, M. A. Ayude, M. Cassanello, R. A. R. Boaventura, and V. J. P. Vilar, "Enhancement of a solar photo-Fenton reaction by using ferrioxalate complexes for the treatment of a synthetic cotton-textile dyeing wastewater," Chemical Engineering Journal, vol. 277, pp. 86-96, 2015.

[54] P. A. Soares, M. Batalha, S. M. A. G. U. Souza, R. A. R. Boaventura, and V. J. P. Vilar, "Enhancement of a solar photo-Fenton reaction with ferric-organic ligands for the treatment of acrylic-textile dyeing wastewater," Journal of Environmental Management, vol. 152, pp. 120-131, 2015.

[55] H. Zheng, Y. Pan, and X. Xiang, "Oxidation of acidic dye eosin Y by the solar photo-Fenton processes," Journal of Hazardous Materials, vol. 141, pp. 457-464, 2007.

[56] A. El-Ghenymy, S. Garcia-Segura, R. M. Rodríguez, E. Brillas, M. S. El Begrani, and B. A. Abdelouahid, "Optimization of the electro-Fenton and solar photoelectro-Fenton treatments of sulfanilic acid solutions using a pre-pilot flow plant by response surface methodology," Journal of Hazardous Materials, vol. 221-222, pp. 288-297, 2012.

[57] S. Irmak, H. I. Yavuz, and O. Erbatur, "Degradation of 4chloro-2-methylphenol in aqueous solution by electroFenton and photoelectro-Fenton processes," Applied Catalysis B: Environmental, vol. 63, pp. 243-248, 2006.

[58] A. R. Khataee, M. Zarei, and L. Moradkhannejhad, "Application of response surface methodology for optimization of azo dye removal by oxalate catalyzed photoelectro-Fenton process using carbon nanotube-PTFE cathode," Desalination, vol. 258, pp. 112-119, 2010.

[59] A. Wang, J. Qu, H. Liu, and J. Ru, "Mineralization of an azo dye acid red 14 by photoelectro-Fenton process using an activated carbon fiber cathode," Applied Catalysis B: Environmental, vol. 84, pp. 393-399, 2008.

[60] A. Serra, X. Domènech, E. Brillas, and J. Peral, "Life cycle assessment of solar photo-Fenton and solar photoelectroFenton processes used for the degradation of aqueous $\alpha$ methylphenylglycine," Journal of Environmental Monitoring, vol. 13, pp. 167-174, 2011.

[61] Y. Zhang, A. Wang, X. Tian et al., "Efficient mineralization of the antibiotic trimethoprim by solar assisted photoelectroFenton process driven by a photovoltaic cell," Journal of Hazardous Materials, vol. 318, pp. 319-328, 2016.

[62] L. C. Almeida, S. Garcia-Segura, N. Bocchi, and E. Brillas, "Solar photoelectro-Fenton degradation of paracetamol using a flow plant with a Pt/air-diffusion cell coupled with a compound parabolic collector: process optimization by response surface methodology," Applied Catalysis B: Environmental, vol. 103, pp. 21-30, 2011.

[63] E. J. Ruiz, A. Hernández-Ramírez, J. M. Peralta-Hernández, C. Arias, and E. Brillas, "Application of solar photoelectro-
Fenton technology to azo dyes mineralization: effect of current density, Fe2+ and dye concentrations," Chemical Engineering Journal, vol. 171, pp. 385-392, 2011.

[64] T. Pérez, S. Garcia-Segura, A. El-Ghenymy, J. L. Nava, and E. Brillas, "Solar photoelectro-Fenton degradation of the antibiotic metronidazole using a flow plant with a Pt/air-diffusion cell and a CPC photoreactor," Electrochimica Acta, vol. 165, pp. 173-181, 2015.

[65] C. Espinoza, J. Romero, L. Villegas, L. Cornejo-Ponce, and R. Salazar, "Mineralization of the textile dye acid yellow 42 by solar photoelectro-Fenton in a lab-pilot plant," Journal of Hazardous Materials, vol. 319, pp. 24-33, 2016.

[66] U. Bali, "Ferrioxalate-mediated photodegradation and mineralization of 4-Chlorophenol," Environmental Science and Pollution Research, vol. 10, pp. 33-38, 2003.

[67] N. Klamerth, S. Malato, A. Agüera, and A. Fernández-Alba, "Photo-Fenton and modified photo-Fenton at neutral $\mathrm{pH}$ for the treatment of emerging contaminants in wastewater treatment plant effluents: a comparison," Water Research, vol. 47, pp. 833-840, 2013.

[68] M. Vedrenne, R. Vasquez-Medrano, D. Prato-Garcia, B. A. Frontana-Uribe, M. Hernandez-Esparza, and J. M. de Andrés, "A ferrous oxalate mediated photo-Fenton system: toward an increased biodegradability of indigo dyed wastewaters," Journal of Hazardous Materials, vol. 243, pp. 292 301, 2012.

[69] S. Garcia-Segura and E. Brillas, "Combustion of textile monoazo, diazo and triazo dyes by solar photoelectro-Fenton: decolorization, kinetics and degradation routes," Applied Catalysis B: Environmental, vol. 181, pp. 681-691, 2016.

[70] S. Garcia-Segura and E. Brillas, "Advances in solar photoelectro-Fenton: decolorization and mineralization of the direct yellow 4 diazo dye using an autonomous solar prepilot plant," Electrochimica Acta, vol. 140, pp. 384-395, 2014.

[71] P. L. Huston and J. J. Pignatello, "Degradation of selected pesticide active ingredients and commercial formulations in water by the photo-assisted Fenton reaction," Water Research, vol. 33, pp. 1238-1246, 1999.

[72] S. S. Martínez and E. V. Uribe, "Enhanced sonochemical degradation of azure B dye by the electroFenton process," Ultrasonics Sonochemistry, vol. 19, pp. 174-178, 2012.

[73] J. J. Pignatello, "Dark and photoassisted iron(3+)-catalyzed degradation of chlorophenoxy herbicides by hydrogen peroxide," Environmental Science \& Technology, vol. 26, pp. 944-951, 1992.

[74] D. Tromans, Oxygen in Water: A Thermodynamic Analysis, 1998.

[75] M. Panizza and G. Cerisola, "Application of diamond electrodes to electrochemical processes," Electrochimica Acta, vol. 51, pp. 191-199, 2005.

[76] S. Garcia-Segura, E. Brillas, L. Cornejo-Ponce, and R. Salazar, "Effect of the $\mathrm{Fe} 3+/ \mathrm{Cu} 2+$ ratio on the removal of the recalcitrant oxalic and oxamic acids by electro-Fenton and solar photoelectro-Fenton," Solar Energy, vol. 124, pp. 242-253, 2016.

[77] A. Wang, Y. Y. Li, and A. L. Estrada, "Mineralization of antibiotic sulfamethoxazole by photoelectro-Fenton treatment using activated carbon fiber cathode and under UVA irradiation," Applied Catalysis B: Environmental, vol. 102, pp. 378-386, 2011. 
[78] E. Isarain-chávez, C. De, L. A. Godínez, E. Brillas, and J. M. Peralta-hernández, "Comparative study of electrochemical water treatment processes for a tannery wastewater effluent," Journal of Electroanalytical Chemistry, vol. 713, pp. 62-69, 2014.

[79] A. Babuponnusami and K. Muthukumar, "Advanced oxidation of phenol: a comparison between Fenton, electro-Fenton, sono-electro-Fenton and photo-electro-Fenton processes," Chemical Engineering Journal, vol. 183, pp. 1-9, 2012.

[80] D. F. Laine and I. F. Cheng, "The destruction of organic pollutants under mild reaction conditions: a review," Microchemical Journal, vol. 85, pp. 183-193, 2007.

[81] L. Feng, N. Oturan, E. D. van Hullebusch, G. Esposito, and M. A. Oturan, "Degradation of anti-inflammatory drug ketoprofen by electro-oxidation: comparison of electro-Fenton and anodic oxidation processes," Environmental Science and Pollution Research, vol. 21, pp. 8406-8416, 2014.

[82] M. Jiménez, I. Oller, M. I. Maldonado et al., "Solar photoFenton degradation of herbicides partially dissolved in water," Catalysis Today, vol. 161, pp. 214-220, 2011.

[83] H. B. Ammar, M. B. Brahim, R. Abdelhédi, and Y. Samet, "Enhanced degradation of metronidazole by sunlight via photo-Fenton process under gradual addition of hydrogen peroxide," Journal of Molecular Catalysis A: Chemical, vol. 420, pp. 222-227, 2016.

[84] R. Salazar, S. Garcia-Segura, M. S. Ureta-Zañartu, and E. Brillas, "Degradation of disperse azo dyes from waters by solar photoelectro-Fenton," Electrochimica Acta, vol. 56, pp. 6371-6379, 2011.

[85] A. Thiam, I. Sirés, F. Centellas, P. L. Cabot, and E. Brillas, "Decolorization and mineralization of Allura Red AC azo dye by solar photoelectro-Fenton: identification of intermediates," Chemosphere, vol. 136, pp. 1-8, 2015.

[86] S. Garcia-Segura, E. B. Cavalcanti, and E. Brillas, "Mineralization of the antibiotic chloramphenicol by solar photoelectroFenton. From stirred tank reactor to solar pre-pilot plant," Applied Catalysis B: Environmental, vol. 144, pp. 588-598, 2014.

[87] M. G. Alalm, A. Tawfik, and S. Ookawara, "Degradation of four pharmaceuticals by solar photo-Fenton process: kinetics and costs estimation," Journal of Environmental Chemical Engineering, vol. 3, pp. 46-51, 2015.

[88] M. M. Ballesteros Martín, J. A. Sánchez Pérez, J. L. García Sánchez, J. L. Casas López, and S. Malato Rodríguez, "Effect of pesticide concentration on the degradation process by combined solar photo-Fenton and biological treatment," Water Research, vol. 43, pp. 3838-3848, 2009.

[89] Y. Samet, M. Ayadi, and R. Abdelhedi, "Degradation of 4chloroguaiacol by dark Fenton and solar photo-Fenton advanced oxidation processes," Water Environment Research, vol. 81, pp. 2389-2397, 2009.

[90] M. Fryda, T. Matthée, S. Mulcahy, M. Höfer, L. Schäfer, and I. Tröster, "Applications of DIACHEM ${ }^{\circledR}$ electrodes in electrolytic water treatment," Electrochemical Society Interface, vol. 12, pp. 40-44, 2003.

[91] J. Vidal, C. Huiliñir, and R. Salazar, "Removal of organic matter contained in slaughterhouse wastewater using a combination of anaerobic digestion and solar photoelectro-Fenton processes," Electrochimica Acta, vol. 210, pp. 163-170, 2016.

[92] J. Casado, J. Fornaguera, and M. I. Galán, "Mineralization of aromatics in water by sunlight-assisted electro-Fenton technology in a pilot reactor," Environmental Science \& Technology, vol. 39, pp. 1843-1847, 2005.

[93] J. Páramo-Vargas, S. G. Granados, M. I. Maldonado-Rubio, and J. M. Peralta-Hernández, "Up to 95\% reduction of chemical oxygen demand of slaughterhouse effluents using Fenton and photo-Fenton oxidation," Environmental Chemistry Letters, vol. 14, pp. 149-154, 2016.

[94] A. Safarzadeh-Amiri, J. R. Bolton, and S. R. Cater, "Ferrioxalate-mediated solar degradation of organic contaminants in water," Solar Energy, vol. 56, pp. 439-443, 1996.

[95] E. Brillas, "A review on the degradation of organic pollutants in waters by UV photoelectro-fenton and solar photoelectrofenton," Journal of the Brazilian Chemical Society, vol. 25, pp. 393-417, 2014.

[96] A. Fujishima and X. Zhang, "Titanium dioxide photocatalysis: present situation and future approaches," Comptes Rendus Chimie, vol. 9, pp. 750-760, 2006.

[97] A. S. González and S. S. Martínez, "Study of the sonophotocatalytic degradation of basic blue 9 industrial textile dye over slurry titanium dioxide and influencing factors," Ultrasonics Sonochemistry, vol. 15, pp. 1038-1042, 2008.

[98] S. Kaneco, M. A. Rahman, T. Suzuki, H. Katsumata, and K. Ohta, "Optimization of solar photocatalytic degradation conditions of bisphenol A in water using titanium dioxide," Journal of Photochemistry and Photobiology A: Chemistry, vol. 163, pp. 419-424, 2004.

[99] J. García-Montaño, L. Pérez-Estrada, I. Oller, M. I. Maldonado, F. Torrades, and J. Peral, "Pilot plant scale reactive dyes degradation by solar photo-Fenton and biological processes," Journal of Photochemistry and Photobiology A: Chemistry, vol. 195, pp. 205-214, 2008

[100] L. O. Conte, J. Farias, E. D. Albizzati, and O. M. Alfano, "Photo-fenton degradation of the herbicide 2,4-dichlorophenoxyacetic acid in laboratory and solar pilot-plant reactors," Industrial and Engineering Chemistry Research, vol. 51, pp. 4181-4191, 2012.

[101] W.-S. S. Kuo, D.-Y. Y. Liu, and C.-F. F. Juang, "Solar photofenton degradation of electro-optical industry wastewater by a pilot-scale fresnel lens assisted IPCC reactor," International Journal of Photoenergy, vol. 2013, pp. 1-7, 2013.

[102] I. Michael, E. Hapeshi, C. Michael et al., "Solar photo-Fenton process on the abatement of antibiotics at a pilot scale: degradation kinetics, ecotoxicity and phytotoxicity assessment and removal of antibiotic resistant enterococci," Water Research, vol. 46, pp. 5621-5634, 2012.

[103] A. Moncayo-Lasso, J. Sanabria, C. Pulgarin, and N. Benítez, "Simultaneous E. coli inactivation and NOM degradation in river water via photo-Fenton process at natural $\mathrm{pH}$ in solar CPC reactor. A new way for enhancing solar disinfection of natural water," Chemosphere, vol. 77, pp. 296-300, 2009.

[104] M. R. A. Silva, A. G. Trovó, and R. F. P. Nogueira, "Degradation of the herbicide tebuthiuron using solar photo-Fenton process and ferric citrate complex at circumneutral $\mathrm{pH}$," Journal of Photochemistry and Photobiology A: Chemistry, vol. 191, pp. 187-192, 2007

[105] A. Zapata, I. Oller, E. Bizani, J. A. Sánchez-Pérez, M. I. Maldonado, and S. Malato, "Evaluation of operational parameters involved in solar photo-Fenton degradation of a commercial pesticide mixture," Catalysis Today, vol. 144, pp. 94-99, 2009. 
[106] E. Ortega-Gómez, M. M. B. Martín, B. E. García, J. A. S. Pérez, and P. F. Ibáñez, "Wastewater disinfection by neutral $\mathrm{pH}$ photo-Fenton: the role of solar radiation intensity," Applied Catalysis B: Environmental, vol. 181, pp. 1-6, 2016.

[107] S. Miralles-Cuevas, I. Oller, A. Agüera, J. A. Sánchez Pérez, and S. Malato, "Strategies for reducing cost by using solar photoFenton treatment combined with nanofiltration to remove microcontaminants in real municipal effluents: toxicity and economic assessment," Chemical Engineering Journal, 2016.

[108] T. F. C. V. Silva, P. A. Soares, D. R. Manenti et al., “An innovative multistage treatment system for sanitary landfill leachate depuration: studies at pilot-scale," Science of The Total Environment, vol. 576, pp. 99-117, 2017.

[109] A. Fujishima, T. N. Rao, and D. A. Tryk, "Titanium dioxide photocatalysis," Journal of Photochemistry and Photobiology C Photochemistry Reviews, vol. 1, pp. 1-21, 2000.

[110] C. Wang, R. Pagel, J. K. Dohrmann, and D. W. Bahnemann, "Antenna mechanism and deaggregation concept: novel mechanistic principles for photocatalysis," Comptes Rendus Chimie, vol. 9, pp. 761-773, 2006.

[111] U. I. Gaya and A. H. Abdullah, "Heterogeneous photocatalytic degradation of organic contaminants over titanium dioxide: a review of fundamentals, progress and problems," Journal of Photochemistry and Photobiology C Photochemistry Reviews, vol. 9, pp. 1-12, 2008.

[112] W. Choi, A. Termin, and M. R. Hoffmann, "The role of metal ion dopants in quantum-sized $\mathrm{TiO} 2$ : correlation between photoreactivity and charge carrier recombination dynamics," The Journal of Physical Chemistry, vol. 98, pp. 13669-13679, 1994.

[113] A. M. Schimpf, S. D. Lounis, E. L. Runnerstrom, D. J. Milliron, and D. R. Gamelin, "Redox chemistries and plasmon energies of photodoped $\mathrm{In} 2 \mathrm{O} 3$ and Sn-doped In2O3 (ITO) nanocrystals," Journal of the American Chemical Society, vol. 137, pp. 518-524, 2015.

[114] T. Ihara, M. Miyoshi, Y. Iriyama, O. Matsumoto, and S. Sugihara, "Visible-light-active titanium oxide photocatalyst realized by an oxygen-deficient structure and by nitrogen doping," Applied Catalysis B: Environmental, vol. 42, pp. 403-409, 2003.

[115] M. Pelaez, A. A. de la Cruz, E. Stathatos, P. Falaras, and D. D. Dionysiou, "Visible light-activated N-F-codoped TiO2 nanoparticles for the photocatalytic degradation of microcystinLR in water," Catalysis Today, vol. 144, pp. 19-25, 2009.

[116] N. B. Saleh, D. J. Milliron, N. Aich, L. E. Katz, H. M. Liljestrand, and M. J. Kirisits, "Importance of doping, dopant distribution, and defects on electronic band structure alteration of metal oxide nanoparticles: implications for reactive oxygen species," Science of The Total Environment, vol. 568, pp. 926-932, 2016.

[117] S. K. Lee, P. K. J. Robertson, A. Mills, D. McStay, N. Elliott, and D. McPhail, "The alteration of the structural properties and photocatalytic activity of $\mathrm{TiO} 2$ following exposure to non-linear irradiation sources," Applied Catalysis B: Environmental, vol. 44, pp. 173-184, 2003.

[118] G. Liu, X. Wang, L. Wang et al., "Drastically enhanced photocatalytic activity in nitrogen doped mesoporous $\mathrm{TiO} 2$ with abundant surface states," Journal of Colloid and Interface Science, vol. 334, pp. 171-175, 2009.

[119] Y. Wang, Q. Wang, X. Zhan, F. Wang, M. Safdar, and J. He, "Visible light driven type II heterostructures and their enhanced photocatalysis properties: a review," Nanoscale, vol. 5, pp. 8326-8339, 2013.

[120] J. Z. Zhang, "Interfacial charge carrier dynamics of colloidal semiconductor nanoparticles," Journal of Physical Chemistry $B$, vol. 104, pp. 7239-7253, 2000.

[121] M. Y. Ghaly, T. S. Jamil, I. E. El-Seesy, E. R. Souaya, and R. A. Nasr, "Treatment of highly polluted paper mill wastewater by solar photocatalytic oxidation with synthesized nano TiO2," Chemical Engineering Journal, vol. 168, pp. 446-454, 2011.

[122] M. Jiménez, M. Ignacio Maldonado, E. M. Rodríguez et al., "Supported TiO 2 solar photocatalysis at semi-pilot scale: degradation of pesticides found in citrus processing industry wastewater, reactivity and influence of photogenerated species," Journal of Chemical Technology and Biotechnology, vol. 90, pp. 149-157, 2015.

[123] P. Magesan, P. Ganesan, and M. J. Umapathy, "Ultrasonicassisted synthesis of doped $\mathrm{TiO} 2$ nanocomposites: characterization and evaluation of photocatalytic and antimicrobial activity," Optik-International Journal for Light and Electron Optics, vol. 127, pp. 5171-5180, 2016.

[124] X. Meng, L. Qi, Z. Xiao et al., "Facile synthesis of direct sunlight-driven anatase $\mathrm{TiO} 2$ nanoparticles by in situ modification with trifluoroacetic acid," Journal of Nanoparticle Research, vol. 14, p. 1176, 2012.

[125] M. U. D. Sheikh, G. A. Naikoo, M. Thomas, M. Bano, and F. Khan, "Solar-assisted photocatalytic reduction of methyl orange azo dye over porous $\mathrm{TiO} 2$ nanostructures," New Journal of Chemistry, vol. 40, pp. 5483-5494, 2016.

[126] F. Wei, H. Zeng, P. Cui, S. Peng, and T. Cheng, "Various $\mathrm{TiO} 2$ microcrystals: controlled synthesis and enhanced photocatalytic activities," Chemical Engineering Journal, vol. 144, pp. 119-123, 2008.

[127] K. H. Leong, P. Monash, S. Ibrahim, and P. Saravanan, "Solar photocatalytic activity of anatase $\mathrm{TiO} 2$ nanocrystals synthesized by non-hydrolitic sol-gel method," Solar Energy, vol. 101, pp. 321-332, 2014.

[128] J. Lin, X. Liu, S. Zhu, Y. Liu, and X. Chen, “Anatase TiO2 nanotube powder film with high crystallinity for enhanced photocatalytic performance," Nanoscale Research Letters, vol. 10, p. 110, 2015.

[129] S. A. Mayén-Hernández, F. Paraguay-Delgado, F. de MoureFlores, G. Casarrubias-Segura, J. J. Coronel-Hernández, and J. Santos-Cruz, "Synthesis of TiO2 thin films with highly efficient surfaces using a sol-gel technique," Materials Science in Semiconductor Processing, vol. 37, pp. 207-214, 2015.

[130] K. Nagaveni, G. Sivalingam, and M. HegdeG. Madras, "Solar photocatalytic degradation of dyes: high activity of combustion synthesized nano TiO2," Applied Catalysis B: Environmental, vol. 48, pp. 83-93, 2004.

[131] P. P. Subha and M. K. Jayaraj, "Solar photocatalytic degradation of methyl orange dye using TiO 2 nanoparticles synthesised by sol-gel method in neutral medium," Journal of Experimental Nanoscience, vol. 10, pp. 1106-1115, 2015.

[132] R. Chatti, S. S. Rayalu, N. Dubey, N. Labhsetwar, and S. Devotta, "Solar-based photoreduction of methyl orange using zeolite supported photocatalytic materials," Solar Energy Materials \& Solar Cells, vol. 91, pp. 180-190, 2007.

[133] N. De la Cruz, R. F. Dantas, J. Giménez, and S. Esplugas, "Photolysis and $\mathrm{TiO} 2$ photocatalysis of the pharmaceutical 
propranolol: solar and artificial light," Applied Catalysis B: Environmental, vol. 130, pp. 249-256, 2013.

[134] J.-M. Herrmann, C. Guillard, J. Disdier, C. Lehaut, S. Malato, and J. Blanco, "New industrial titania photocatalysts for the solar detoxification of water containing various pollutants," Applied Catalysis B: Environmental, vol. 35, pp. 281-294, 2002.

[135] M. M. Higarashi and W. F. Jardim, "Remediation of pesticide contaminated soil using $\mathrm{TiO} 2$ mediated by solar light," Catalysis Today, vol. 76, pp. 201-207, 2002.

[136] H. Barndõk, D. Hermosilla, C. Han, D. D. Dionysiou, C. Negro, and Á. Blanco, "Degradation of 1,4-dioxane from industrial wastewater by solar photocatalysis using immobilized NF-TiO 2 composite with monodisperse $\mathrm{TiO} 2$ nanoparticles," Applied Catalysis B: Environmental, vol. 180, pp. 44-52, 2016.

[137] W. S. Kuo and P. H. Ho, "Solar photocatalytic decolorization of methylene blue in water," Chemosphere, vol. 45, pp. 77-83, 2001.

[138] M. Muruganandham, N. Shobana, and M. Swaminathan, "Optimization of solar photocatalytic degradation conditions of reactive yellow 14 azo dye in aqueous TiO2," Journal of Molecular Catalysis A: Chemical, vol. 246, pp. 154-161, 2006.

[139] B. Neppolian, H. C. Choi, S. Sakthivel, B. Arabindoo, and V. Murugesan, "Solar/UV-induced photocatalytic degradation of three commercial textile dyes," Journal of Hazardous Materials, vol. 89, pp. 303-317, 2002.

[140] A. Durán and J. M. Monteagudo, "Solar photocatalytic degradation of reactive blue 4 using a Fresnel lens," Water Research, vol. 41, pp. 690-698, 2007.

[141] T. S. Jamil, T. A. Gad-Allah, M. E. M. Ali, and M. N. B. Momba, "Utilization of nano size $\mathrm{TiO} 2$ for degradation of phenol enrich water by solar photocatalytic oxidation," Desalination and Water Treatment, vol. 53, pp. 11011106, 2015.

[142] A. Kaur, A. Umar, and S. K. Kansal, "Sunlight-driven photocatalytic degradation of non-steroidal anti-inflammatory drug based on $\mathrm{TiO} 2$ quantum dots," Journal of Colloid and Interface Science, vol. 459, pp. 257-263, 2015.

[143] I. Salgado-Tránsito, A. E. Jiménez-González, M. L. RamónGarcía, C. A. Pineda-Arellano, and C. A. Estrada-Gasca, "Design of a novel CPC collector for the photodegradation of carbaryl pesticides as a function of the solar concentration ratio," Solar Energy, vol. 115, pp. 537-551, 2015.

[144] M. H. Habibi, N. Talebian, and J.-H. Choi, "The effect of annealing on photocatalytic properties of nanostructured titanium dioxide thin films," Dyes and Pigments, vol. 73, pp. 103-110, 2007.

[145] Y.-Q. Hou, D.-M. Zhuang, G. Zhang, M. Zhao, and M.-S. $\mathrm{Wu}$, "Influence of annealing temperature on the properties of titanium oxide thin film," Applied Surface Science, vol. 218, pp. 98-106, 2003.

[146] N. Liu, I. Paramasivam, M. Yang, and P. Schmuki, "Some critical factors for photocatalysis on self-organized $\mathrm{TiO} 2$ nanotubes," Journal of Solid State Electrochemistry, vol. 16, pp. 3499-3504, 2012.

[147] N. R. Mathews, E. R. Morales, M. A. Cortés-Jacome, and J. A. Toledo Antonio, "TiO2 thin films - influence of annealing temperature on structural, optical and photocatalytic properties," Solar Energy, vol. 83, pp. 1499-1508, 2009.
[148] S. Nakade, M. Matsuda, S. Kambe et al., "Dependence of $\mathrm{TiO} 2$ nanoparticle preparation methods and annealing temperature on the efficiency of dye-sensitized solar cells," The Journal of Physical Chemistry B, vol. 106, pp. 1000410010, 2002.

[149] P. Roy, S. Berger, and P. Schmuki, "TiO2 nanotubes: synthesis and applications," Angewandte Chemie, International Edition, vol. 50, pp. 2904-2939, 2011.

[150] M. Andersson, L. Österlund, S. Ljungström, and A. Palmqvist, "Preparation of nanosize anatase and rutile $\mathrm{TiO} 2$ by hydrothermal treatment of microemulsions and their activity for photocatalytic wet oxidation of phenol," The Journal of Physical Chemistry B, vol. 106, pp. 10674-10679, 2002.

[151] A. Sclafani and J. M. Herrmann, "Comparison of the photoelectronic and photocatalytic activities of various anatase and rutile forms of titania in pure liquid organic phases and in aqueous solutions," The Journal of Physical Chemistry, vol. 100, pp. 13655-13661, 1996.

[152] Y. K. Kho, A. Iwase, W. Y. Teoh, L. Mädler, A. Kudo, and R. Amal, "Photocatalytic H 2 evolution over TiO 2 nanoparticles. The synergistic effect of anatase and rutile," Journal of Physical Chemistry C, vol. 114, pp. 2821-2829, 2010.

[153] G. Li, L. Chen, M. E. Graham, and K. A. Gray, "A comparison of mixed phase titania photocatalysts prepared by physical and chemical methods: the importance of the solid-solid interface," Journal of Molecular Catalysis A: Chemical, vol. 275, pp. 30-35, 2007.

[154] B. K. Mutuma, G. N. Shao, W. D. Kim, and H. T. Kim, "Solgel synthesis of mesoporous anatase-brookite and anatasebrookite-rutile $\mathrm{TiO} 2$ nanoparticles and their photocatalytic properties," Journal of Colloid and Interface Science, vol. 442, pp. 1-7, 2015.

[155] M. Yan, F. Chen, J. Zhang, and M. Anpo, "Preparation of controllable crystalline titania and study on the photocatalytic properties," The Journal of Physical Chemistry B, vol. 109, pp. 8673-8678, 2005.

[156] D. Chen and A. K. Ray, "Photocatalytic kinetics of phenol and its derivatives over UV irradiated TiO2," Applied Catalysis B: Environmental, vol. 23, pp. 143-157, 1999.

[157] J. Giménez, D. Curcó, and M. A. Queral, "Photocatalytic treatment of phenol and 2,4-dichlorophenol in a solar plant in the way to scaling-up," Catalysis Today, vol. 54, pp. 229243, 1999.

[158] S. Parra, J. Olivero, and C. Pulgarin, "Relationships between physicochemical properties and photoreactivity of four biorecalcitrant phenylurea herbicides in aqueous $\mathrm{TiO} 2$ suspension," Applied Catalysis B: Environmental, vol. 36, pp. 75-85, 2002.

[159] R. A. Torres, J. I. Nieto, E. Combet, C. Pétrier, and C. Pulgarin, "Influence of $\mathrm{TiO} 2$ concentration on the synergistic effect between photocatalysis and high-frequency ultrasound for organic pollutant mineralization in water," Applied Catalysis B: Environmental, vol. 80, pp. 168-175, 2008.

[160] C. L. Bahena, S. S. Martínez, D. M. Guzmán, and M. del Refugio Trejo Hernández, "Sonophotocatalytic degradation of alazine and gesaprim commercial herbicides in $\mathrm{TiO} 2$ slurry," Chemosphere, vol. 71, pp. 982-989, 2008.

[161] C. Berberidou, I. Poulios, N. P. Xekoukoulotakis, and D. Mantzavinos, "Sonolytic, photocatalytic and sonophotocatalytic degradation of malachite green in aqueous solutions," Applied Catalysis B: Environmental, vol. 74, pp. 63-72, 2007. 
[162] Y.-C. Chen, A. V. Vorontsov, and P. G. Smirniotis, "Enhanced photocatalytic degradation of dimethyl methylphosphonate in the presence of low-frequency ultrasound," Photochemical \& Photobiological Sciences, vol. 2, pp. 694698, 2003.

[163] K. S. Suslick, "The chemical effects of ultrasound," Scientific American, vol. 260, pp. 80-86, 1989.

[164] P. R. Gogate and A. B. Pandit, "Sonophotocatalytic reactors for wastewater treatment: a critical review," AICHE Journal, vol. 50, pp. 1051-1079, 2004.

[165] A. D. Paola, S. Ikeda, G. Marcì, B. Ohtani, and L. Palmisano, "Transition metal doped TiO2: physical properties and photocatalytic behaviour," International Journal of Photoenergy, vol. 3, pp. 171-176, 2001.

[166] T. Preocanin and N. Kallay, "Point of zero charge and surface charge density of $\mathrm{TiO} 2$ in aqueous electrolyte solution as obtained by potentiometric mass titration," Croatica Chemica Acta, vol. 79, pp. 95-106, 2006.

[167] J. H. O. S. Pereira, A. C. Reis, O. C. Nunes, M. T. Borges, V. J. P. Vilar, and R. A. R. Boaventura, "Assessment of solar driven $\mathrm{TiO} 2$-assisted photocatalysis efficiency on amoxicillin degradation," Environmental Science and Pollution Research, vol. 21, pp. 1292-1303, 2014.

[168] V. Augugliaro, C. Baiocchi, A. B. Prevot et al., “Azo-dyes photocatalytic degradation in aqueous suspension of $\mathrm{TiO} 2$ under solar irradiation," Chemosphere, vol. 49, pp. 12231230, 2002.

[169] P. Fernández, J. Blanco, C. Sichel, and S. Malato, "Water disinfection by solar photocatalysis using compound parabolic collectors," Catalysis Today, vol. 101, pp. 345-352, 2005.

[170] I. García-Fernández, I. Fernández-Calderero, M. Inmaculada Polo-López, and P. Fernández-Ibáñez, "Disinfection of urban effluents using solar $\mathrm{TiO} 2$ photocatalysis: a study of significance of dissolved oxygen, temperature, type of microorganism and water matrix," Catalysis Today, vol. 240, pp. 30-38, 2015.

[171] I. Oller, W. Gernjak, M. I. Maldonado, L. A. Pérez-Estrada, J. A. Sánchez-Pérez, and S. Malato, "Solar photocatalytic degradation of some hazardous water-soluble pesticides at pilotplant scale," Journal of Hazardous Materials, vol. 138, pp. 507-517, 2006.

[172] J. Wiszniowski, D. Robert, J. Surmacz-Gorska, K. Miksch, S. Malato, and J. V. Weber, "Solar photocatalytic degradation of humic acids as a model of organic compounds of landfill leachate in pilot-plant experiments: influence of inorganic salts," Applied Catalysis B: Environmental, vol. 53, pp. 127-137, 2004.

[173] M. Jiménez-Tototzintle, I. Oller, A. Hernández-Ramírez, S. Malato, and M. I. Maldonado, "Remediation of agro-food industry effluents by biotreatment combined with supported TiO2/H2O2 solar photocatalysis," Chemical Engineering Journal, vol. 273, pp. 205-213, 2015.

[174] C. A. P. Arellano and S. S. Martínez, "Effects of pH on the degradation of aqueous ferricyanide by photolysis and photocatalysis under solar radiation," Solar Energy Materials \& Solar Cells, vol. 94, pp. 327-332, 2010.

[175] Q. Xiao, J. Zhang, C. Xiao, Z. Si, and X. Tan, "Solar photocatalytic degradation of methylene blue in carbon-doped TiO2 nanoparticles suspension," Solar Energy, vol. 82, pp. 706-713, 2008.
[176] J.-M. Herrmann, J. Matos, J. Disdier et al., "Solar photocatalytic degradation of 4-chlorophenol using the synergistic effect between titania and activated carbon in aqueous suspension," Catalysis Today, vol. 54, pp. 255265, 1999.

[177] S. Adishkumar, S. Kanmani, J. Rajesh Banu, and I. Tae Yeom, "Evaluation of bench-scale solar photocatalytic reactors for degradation of phenolic wastewaters," Desalination and Water Treatment, vol. 57, pp. 16862-16870, 2016.

[178] G. Sagawe, R. J. Brandi, D. Bahnemann, and A. E. Cassano, "Photocatalytic reactors for treating water pollution with solar illumination: a simplified analysis for n-steps flow reactors with recirculation," Solar Energy, vol. 79, pp. 262-269, 2005.

[179] P. A. Soares, T. F. C. V. Silva, A. Ramos Arcy, S. M. A. G. U. Souza, R. A. R. Boaventura, and V. J. P. Vilar, "Assessment of AOPs as a polishing step in the decolourisation of bio-treated textile wastewater: technical and economic considerations," Journal of Photochemistry and Photobiology A: Chemistry, vol. 317, pp. 26-38, 2016.

[180] L. S. J. Jordá, M. M. B. Martín, E. O. Gómez et al., “Economic evaluation of the photo-Fenton process. Mineralization level and reaction time: the keys for increasing plant efficiency," Journal of Hazardous Materials, vol. 186, pp. 1924-1929, 2011.

[181] M. Gar Alalm, A. Tawfik, and S. Ookawara, "Comparison of solar $\mathrm{TiO} 2$ photocatalysis and solar photo-Fenton for treatment of pesticides industry wastewater: operational conditions, kinetics, and costs," Journal of Water Process Engineering, vol. 8, pp. 55-63, 2015.

[182] A. Zapata, S. Malato, J. A. Sánchez-Pérez, I. Oller, and M. I. Maldonado, "Scale-up strategy for a combined solar photoFenton/biological system for remediation of pesticidecontaminated water," Catalysis Today, vol. 151, pp. 100106, 2010.

[183] M. N. Chong, B. Jin, C. W. K. Chow, and C. Saint, "Recent developments in photocatalytic water treatment technology: a review," Water Research, vol. 44, pp. 2997-3027, 2010.

[184] M. I. Maldonado, P. C. Passarinho, I. Oller et al., "Photocatalytic degradation of EU priority substances: a comparison between $\mathrm{TiO} 2$ and Fenton plus photo-Fenton in a solar pilot plant," Journal of Photochemistry and Photobiology A: Chemistry, vol. 185, pp. 354-363, 2007.

[185] J. M. Monteagudo, A. Durán, I. San Martín, and M. Aguirre, "Effect of continuous addition of $\mathrm{H} 2 \mathrm{O} 2$ and air injection on ferrioxalate-assisted solar photo-Fenton degradation of Orange II," Applied Catalysis B: Environmental, vol. 89, pp. 510-518, 2009.

[186] R. F. P. Nogueira, M. R. A. Silva, and A. G. Trovó, "Influence of the iron source on the solar photo-Fenton degradation of different classes of organic compounds," Solar Energy, vol. 79, pp. 384-392, 2005.

[187] M. C. Ortega-Liébana, E. Sánchez-López, J. Hidalgo-Carrillo, A. Marinas, J. M. Marinas, and F. J. Urbano, “A comparative study of photocatalytic degradation of 3-chloropyridine under UV and solar light by homogeneous (photo-Fenton) and heterogeneous (TiO 2) photocatalysis," Applied Catalysis B: Environmental, vol. 127, pp. 316-322, 2012.

[188] T. Soltani and M. H. Entezari, "Solar-Fenton catalytic degradation of phenolic compounds by impure bismuth ferrite nanoparticles synthesized via ultrasound," Chemical Engineering Journal, vol. 251, pp. 207-216, 2014. 
[189] A. G. Trovó, R. F. P. Nogueira, A. Agüera, A. R. FernandezAlba, C. Sirtori, and S. Malato, "Degradation of sulfamethoxazole in water by solar photo-Fenton. Chemical and toxicological evaluation," Water Research, vol. 43, pp. 39223931, 2009.

[190] J. Guzmán, R. Mosteo, J. Sarasa, J. A. Alba, and J. L. Ovelleiro, "Evaluation of solar photo-Fenton and ozone based processes as citrus wastewater pre-treatments," Separation and Purification Technology, vol. 164, pp. 155-162, 2016.

[191] J. A. Sánchez Pérez, P. Soriano-Molina, G. Rivas, J. L. García Sánchez, J. L. Casas López, and J. M. Fernández Sevilla, "Effect of temperature and photon absorption on the kinetics of micropollutant removal by solar photo-Fenton in raceway pond reactors," Chemical Engineering Journal, vol. 310, pp. 464-472, 2017.

[192] V. Aurioles-López, M. I. Polo-López, P. Fernández-Ibáñez, A. López-Malo, and E. R. Bandala, "Effect of iron salt counter ion in dose-response curves for inactivation of fusarium solani in water through solar driven Fenton-like processes," Physics and Chemistry of the Earth, Parts $A / B / C$, vol. 91, pp. 46-52, 2016.

[193] J. Vergara-Sánchez and S. Silva-Martínez, "Degradation of water polluted with used cooking oil by solar photolysis, Fenton and solar photo Fenton," Water Science and Technology, vol. 62, p. 77, 2010.

[194] B. Garza-Campos, E. Brillas, A. Hernández-Ramírez, A. El-Ghenymy, J. L. Guzmán-Mar, and E. J. Ruiz-Ruiz, "Salicylic acid degradation by advanced oxidation processes. Coupling of solar photoelectro-Fenton and solar heterogeneous photocatalysis," Journal of Hazardous Materials, vol. 319, pp. 34-42, 2015.

[195] C. Flox, P. L. Cabot, F. Centellas et al., "Solar photoelectroFenton degradation of cresols using a flow reactor with a boron-doped diamond anode," Applied Catalysis B: Environmental, vol. 75, pp. 17-28, 2007.

[196] E. Brillas and S. Garcia-Segura, "Solar Photoelectro-Fenton degradation of acid Orange 7 azo dye in a solar flow plant: optimization by response surface methodology," Water Conservation Science and Engineering, vol. 1, pp. 83-94, 2016.

[197] H. Olvera-Vargas, N. Oturan, M. A. Oturan, and E. Brillas, "Electro-Fenton and solar photoelectro-Fenton treatments of the pharmaceutical ranitidine in pre-pilot flow plant scale," Separation and Purification Technology, vol. 146, pp. 127135, 2015.

[198] F. C. Moreira, S. Garcia-Segura, V. J. P. Vilar, R. A. R. Boaventura, and E. Brillas, "Decolorization and mineralization of sunset yellow FCF azo dye by anodic oxidation, electro-Fenton, UVA photoelectro-Fenton and solar photoelectro-Fenton processes," Applied Catalysis B: Environmental, vol. 142-143, pp. 877-890, 2013.

[199] A. El-Ghenymy, P. L. Cabot, F. Centellas et al., "Mineralization of sulfanilamide by electro-Fenton and solar photoelectro-Fenton in a pre-pilot plant with a Pt/air-diffusion cell," Chemosphere, vol. 91, pp. 1324-1331, 2013.

[200] F. Gozzi, I. Sirés, A. Thiam, S. C. de Oliveira, A. M. Junior, and E. Brillas, "Treatment of single and mixed pesticide formulations by solar photoelectro-Fenton using a flow plant," Chemical Engineering Journal, 2016.

[201] F. C. Moreira, J. Soler, A. Fonseca et al., "Electrochemical advanced oxidation processes for sanitary landfill leachate remediation: evaluation of operational variables," Applied Catalysis B: Environmental, vol. 182, pp. 161-171, 2016.
[202] B. R. Garza-Campos, J. L. Guzmán-Mar, L. H. Reyes, E. Brillas, A. Hernández-Ramírez, and E. J. Ruiz-Ruiz, "Coupling of solar photoelectro-Fenton with a BDD anode and solar heterogeneous photocatalysis for the mineralization of the herbicide atrazine," Chemosphere, vol. 97, pp. 26-33, 2014.

[203] T. Oyama, A. Aoshima, S. Horikoshi, H. Hidaka, J. Zhao, and N. Serpone, "Solar photocatalysis, photodegradation of a commercial detergent in aqueous $\mathrm{TiO} 2$ dispersions under sunlight irradiation," Solar Energy, vol. 77, pp. 525-532, 2004.

[204] Y. Wang, "Solar photocatalytic degradation of eight commercial dyes in $\mathrm{TiO} 2$ suspension," Water Research, vol. 34, pp. 990-994, 2000.

[205] D. S. Bhatkhande, V. G. Pangarkar, and A. A. C. M. Beenackers, "Photocatalytic degradation of nitrobenzene using titanium dioxide and concentrated solar radiation: chemical effects and scaleup," Water Research, vol. 37, pp. 1223-1230, 2003.

[206] M. Muruganandham and M. Swaminathan, "Solar photocatalytic degradation of a reactive azo dye in $\mathrm{TiO} 2$-suspension," Solar Energy Materials \& Solar Cells, vol. 81, pp. 439-457, 2004.

[207] J. Carbajo, M. Jiménez, S. Miralles, S. Malato, M. Faraldos, and A. Bahamonde, "Study of application of titania catalysts on solar photocatalysis: influence of type of pollutants and water matrices," Chemical Engineering Journal, vol. 291, pp. 64-73, 2016.

[208] D. Kanakaraju, C. A. Motti, B. D. Glass, and M. Oelgemöller, "Solar photolysis versus $\mathrm{TiO} 2$-mediated solar photocatalysis: a kinetic study of the degradation of naproxen and diclofenac in various water matrices," Environmental Science and Pollution Research, vol. 23, no. 17, pp. 17437-17448, 2016.

[209] M. Kositzi, I. Poulios, S. Malato, J. Caceres, and A. Campos, "Solar photocatalytic treatment of synthetic municipal wastewater," Water Research, vol. 38, pp. 1147-1154, 2004.

[210] M. E. Borges, M. Sierra, J. Méndez-Ramos, P. AcostaMora, J. C. Ruiz-Morales, and P. Esparza, "Solar degradation of contaminants in water: $\mathrm{TiO} 2$ solar photocatalysis assisted by up-conversion luminescent materials," Solar Energy Materials \& Solar Cells, vol. 155, pp. 194-201, 2016.

[211] Y. Y. Gurkan, N. Turkten, A. Hatipoglu, and Z. Cinar, "Photocatalytic degradation of cefazolin over $\mathrm{N}$-doped $\mathrm{TiO} 2$ under UV and sunlight irradiation: prediction of the reaction paths via conceptual DFT," Chemical Engineering Journal, vol. 184, pp. 113-124, 2012.

[212] J. Sun, L. Qiao, S. Sun, and G. Wang, "Photocatalytic degradation of Orange $\mathrm{G}$ on nitrogen-doped $\mathrm{TiO} 2$ catalysts under visible light and sunlight irradiation," Journal of Hazardous Materials, vol. 155, pp. 312-319, 2008.

[213] D. Wang, Y. Wang, X. Li, Q. Luo, J. An, and J. Yue, “Sunlight photocatalytic activity of polypyrrole- $\mathrm{TiO} 2$ nanocomposites prepared by "in situ" method," Catalysis Communications, vol. 9, pp. 1162-1166, 2008. 

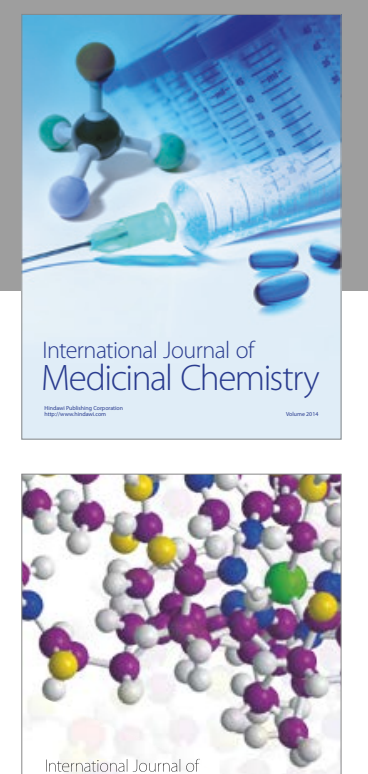

Carbohydrate Chemistry

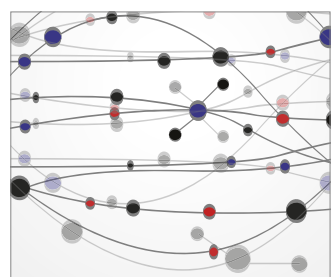

The Scientific World Journal
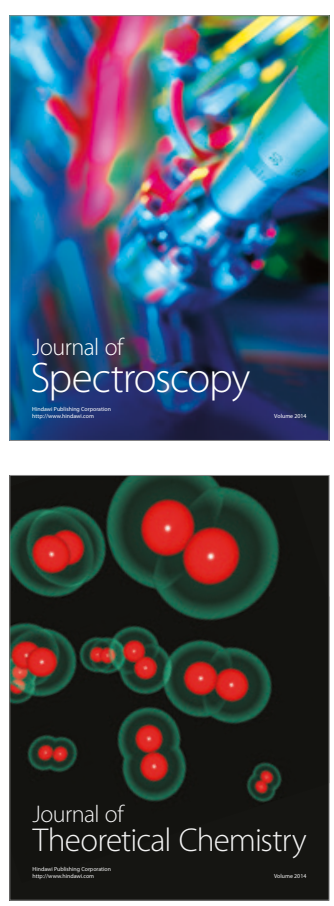
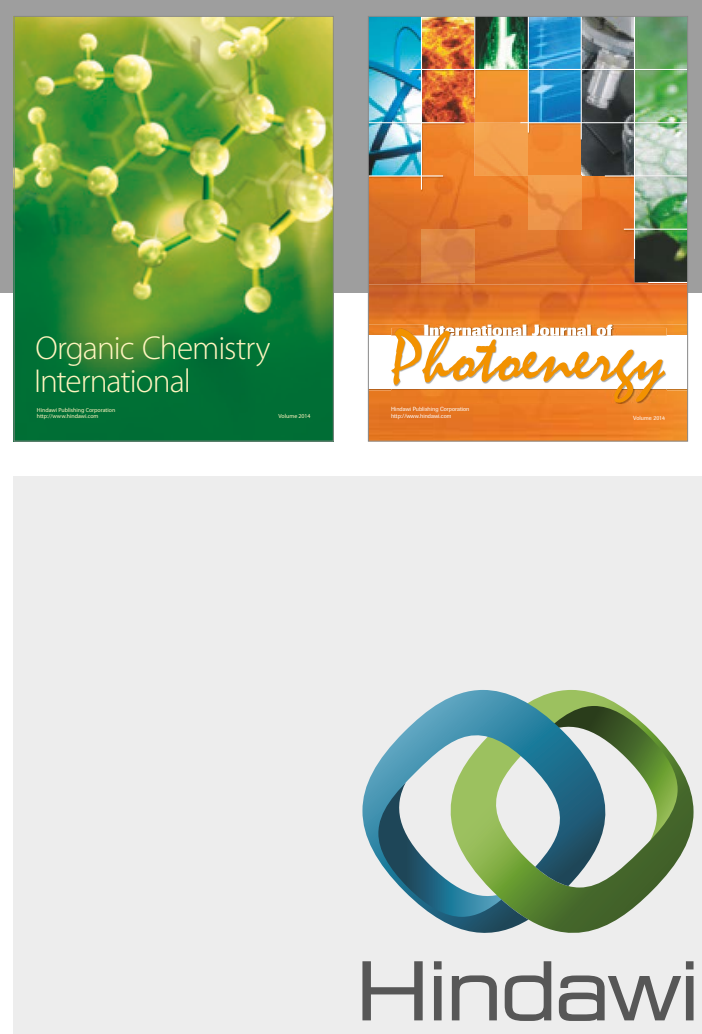

Submit your manuscripts at

https://www.hindawi.com

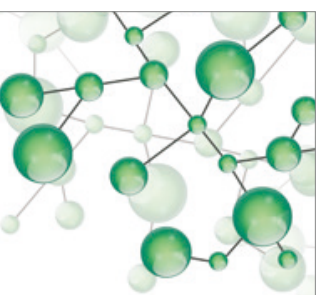

International Journal of

Inorganic Chemistry

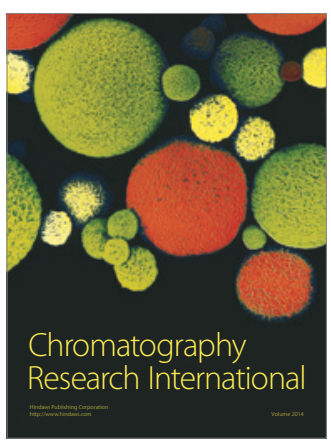

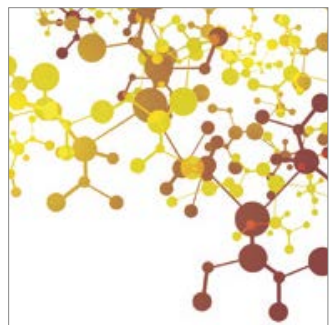

Applied Chemistry
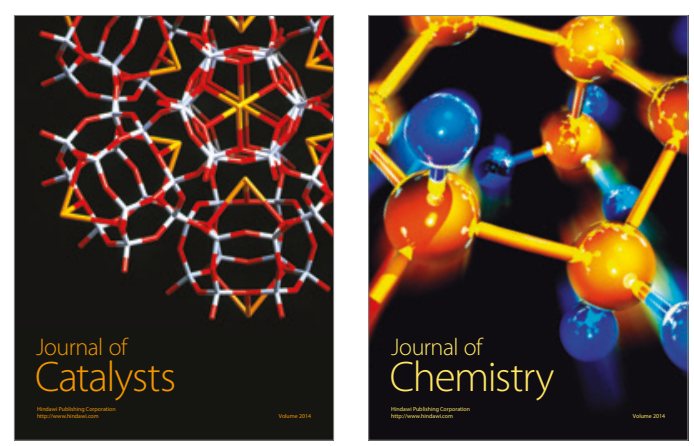
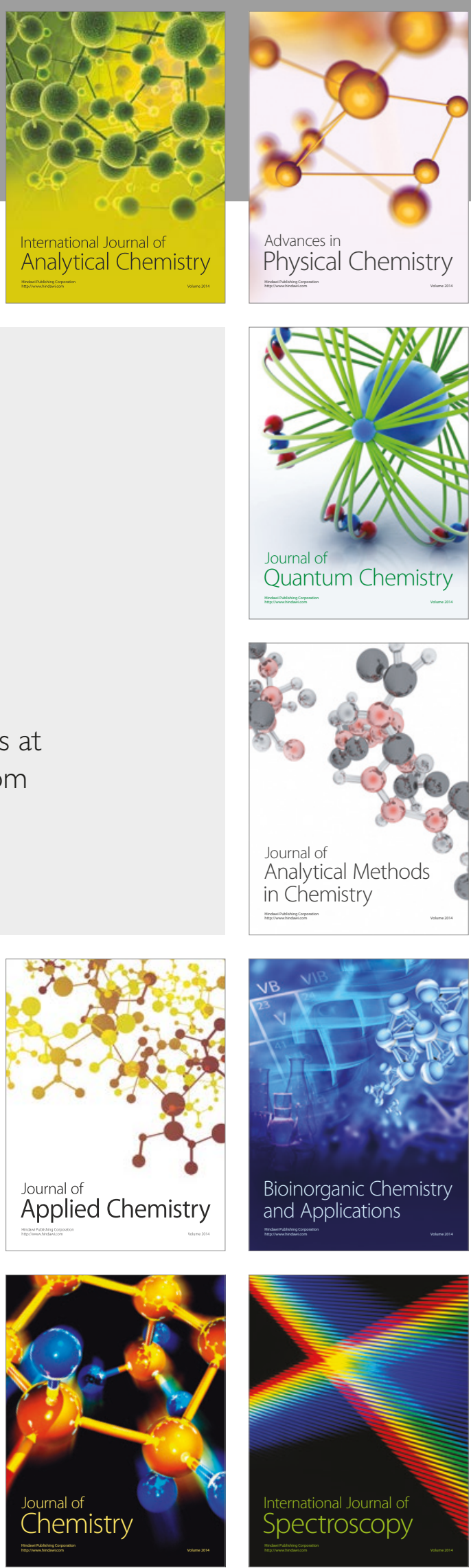